\title{
An Economic Development Evaluation Based on the OpenStreetMap Road Network Density: The Case Study of 85 Cities in China
}

\author{
Bo Liu ${ }^{1}$, Yu Shi ${ }^{1}$, Da-Jun Li ${ }^{1}{ }^{*}$, Yan-Dong Wang ${ }^{2}$, Gabriela Fernandez ${ }^{3}$ \\ and Ming-Hsiang Tsou ${ }^{3}$ D \\ 1 Faculty of Geomatics, East China University of Technology, 418\# Guanglan Road, Nanchang 330013, \\ China; liubo@ecut.edu.cn (B.L.); yushi19930807@outlook.com (Y.S.) \\ 2 State Key Laboratory of Information Engineering in Surveying, Mapping and Remote Sensing, \\ Wuhan University, 129\# Luoyu Road, Wuhan 430079, China; ydwang@whu.edu.cn \\ 3 Department of Geography, Center for Human Dynamics in the Mobile Age (HDMA), \\ San Diego State University, 5500 Campanile Drive, San Diego, CA 92182-4493, USA; \\ gfernandez2@sdsu.edu (G.F.); mtsou@mail.sdsu.edu (M.-H.T.) \\ * Correspondence: djli@ecut.edu.cn
}

Received: 14 July 2020; Accepted: 17 August 2020; Published: 28 August 2020

\begin{abstract}
The evaluation of urban economies has been one key concern identified by scholars. In the past, most research methods on urban development assessments have been based on statistical data, and the analysis results have been presented in the form of statistical tables. Moreover, the development of urban road networks reflects the status of urban development and spatial metrics, which are obtained from the urban road network which can be used to evaluate the growth of the urban economy. The OpenStreetMap (OSM) is collected through crowdsourcing, and the OSM road network has the characteristics of a simplified and efficient approach to collect data, update data, free available data, etc. Therefore, in this paper, the OSM road network density is used as a spatial metric which is taken as the main study subject, to evaluate the economic development of Chinese cities. In our experiment, results show that there is a significant regression correlation between the OSM road network density and municipal gross domestic product (GDP). For the 85 selected Chinese cities, a total of 71 cities with residuals between -0.1 and 0.1 account for $83.53 \%$, and a total of 79 cities with residuals between -0.2 and 0.2 account for $92.94 \%$. Therefore, it is apparent that the OSM road network density can be used as a spatial metric to evaluate the municipal GDP, and as a result, can be used by local governments and scholars to estimate, evaluate, and forecast the urban economic development of China.
\end{abstract}

Keywords: OpenStreetMap (OSM); road network density; urban economy; regression analysis; spatial metric

\section{Introduction}

In recent years, the rapid development of remote sensing, volunteered geographic information (VGI) and other technologies, spatial data acquisition have become easier to employ. As a result, there is more and more research on land-cover, land-use, and urban development using spatial metrics [1-8]. A few different approaches used to represent spatial concepts have resulted in the development of various spatial metrics [1-4]. More commonly applied metrics used by scholars have included patch size, dominance, number of patches, and density, edge length and density, nearest neighbor distance, fractal dimension, contagion, etc. [4]. Herold et al. [5] used spatial metrics and texture measures to describe the spatial characteristics of land-cover objects within each land-use 
region as derived from interpreted aerial photographs. These spatial metrics include percentage of landscape, patch density, mean patch size, area standard deviation, edge density, largest patch index, Euclidean mean nearest neighbor distance, Euclidean nearest neighbor distance standard deviation, area weighted mean patch fractal dimension, fractal dimension standard deviation, etc. Herold et al. [6] argued that remote sensing and spatial metrics lead to an improved understanding and representation of urban dynamics while helping to develop alternative conceptions of urban spatial structure and change. In order to cover as many metrics as possible, Reis et al. [7] presented an extended, updated, and more thorough portfolio of spatial metrics to measure the urban growth and urban shrinkage patterns. In their paper, spatial metrics were defined as the quantitative measures used to assess the spatial characteristics of urban settlements. Reis et al. [8] assembled spatial metrics into three groups: landscape metrics; geo-spatial metrics, and spatial statistics. They indicated that landscape metrics such as fractal dimension, shape, mean perimeter-area ratio mean shape, etc., have been traditionally used to quantify several aspects of landscape configuration and composition. Geospatial metrics has mostly been used to measure urban spatial patterns. However, there are metrics that are similar between geospatial metrics and landscape metrics. Moreover, an important difference between the metrics from landscape metrics is that the latter include a set of metrics that evolved in a "top-down" approach. Spatial statistics are metrics based on statistical tools, and these spatial metrics are often used in combination with regression and spatial econometric models. In this paper, the main purpose of this research is to discuss whether the OpenStreetMap (OSM) road network density can be used to evaluate the level of urban economic development in cities. Firstly, using a regression model to establish the relationship between the OSM road network density and municipal gross domestic product (GDP) from 2014 to 2017. Then, the OSM road network density and municipal GDP in 2018 were used to verify the regression model, to discuss whether the OSM road network density can be used as a spatial metric to evaluate the level of urban economic development in cities. Because the OSM road network has the advantage to be an easier approach to collect data, in a more efficient way, update data, and provide free available data, etc. If we can use the OSM road network density to evaluate the level of urban economic development in cities, then this research can help policy makers in China monitor and evaluate their cities towards more transparent and efficient cities. Moreover, the OSM road network density is based on statistics and mainly uses a regression model, therefore, we take the OSM road network density as a spatial metric to evaluate the level of urban development and transparency in cites.

In general, there is a significant correlation between urbanization and the level of economic development, and it seems that each country or region conforms to this rule to a certain degree [8-10], and urbanization has been a defining global phenomenon and a key driving force for social and economic development during the past century [11,12]. Despite China being the world's largest developed country, its urbanization has progressed at an unprecedented rate [13], as urbanization has shifted due to the rise of industries and population in and around cities, facilitating the development of economies of scale [14]. Cai et al. [15] indicated that the improvement of urban infrastructure attracted corporate investments, created new jobs, and led to an influx of labor. Therefore, the proportion of China's population living in cities increased from $17.9 \%$ in 1978 to $58.5 \%$ in 2017 [16]. Heshmati et al. [17] calculated a multi-dimensional composite index of urban infrastructure analyzing 31 provinces and six regions in China during 2005 to 2014, and indicated that the economy, employment, human development, utilities, and technology components of urban infrastructure had positive and significant effects on China's urbanization, and suggested that the government should guide investments to more efficient transportation systems that improve the development of a city.

As described in the above literature, the efficient transportation systems have a positive impact on urbanization, and the higher the urbanization level of a city, the greater the density of its road network, the higher economic level of a city. In order to discuss the relationship between the road network density and urban economic development, based on geospatial metrics and spatial statistics, many researchers have studied the relationship between spatial metrics and urban economic development. Yu et al. [18] 
explored the role of the motorway in the evolution of spatial economic agglomerations, they indicated that an improvement in the motorway network lead to a higher degree of geographic concentration of economic activities. Jiao et al. [19] studied the relation between road accessibility and economic growth in China from 1990 to 2010. They studied a total of 337 cities in China and explored the bivariate analysis framework of accessibility, economic growth, and increased rates. The analysis showed that there is a significant positive relationship between the accessibility and economic growth of a city, and that the economic increased rates are largely influenced by the change of accessibility. Worku [20] studied the trends, stock of achievements, and impact of the road network on the economic growth of Ethiopia, Africa. He indicated that the impact of the road network was seen to be less strong on the agricultural GDP growth, but had pronounced impact of the industrial and service sector of GDP. Ivanova and Masarova [21] used the series and correlation method to analyze the effects of road infrastructure development on the economic growth and competitiveness of Slovak's economy, they indicated that the road infrastructure was a prerequisite for economic growth. Beyzatlar et al. [22] investigated the Granger causality relationship between income and transportation of EU-15 countries. They indicated that there was an endogenous relationship between income and transportation. Gao et al. [23] studied the relationship between the comprehensive transportation freight index and GDP in China. They indicated that the volume of freight traffic and freight turnover in China are positively correlated with GDP. Fan and Chan-Kang [24] studied the impact of road investment on the overall economic growth, rural and urban growth, and rural and urban poverty reduction. They indicated that road investments yielded the highest economic returns in the eastern and central regions of China, while the contributions to poverty reduction were the greatest in western China. It can be seen from the above research that the road network can be correlated with GDP, and most researchers have used regression analysis to investigate the relationship between spatial metrics and urban economic development in cities.

In the last decade, OSM has achieved tremendous development with the popularity and development of the Internet. OSM is a user-generated street map, most of the data sources are provided by the public or volunteers [25], and until now, there are more than six million registered members in the world, and more than six billion nodes in the OSM database [26]. Today, the OSM has become available to be applied in many ways, such as 3D city modeling, road updating, etc. [27-37]. For example, based on the free geographic data provided by the OSM project and the public domain height information provided by the Shuttle Radar Topography Mission, Over et al. [27] studied the prospects of using an interactive 3D city model in Germany and pointed out that the point of interest (POI) in the OSM data provides new opportunities for 3D city modeling. Fonte et al. $[28,29]$ used the OSM data and GlobeLand30 image data to process, resulting in a more accurate and detailed land use coverage map, and more details can be shown by this method than any other methods. Mobasheri et al. [34] explored the feasibility of using the OSM data as geo-navigation data in several German cities by using factors such as the number of features and integrity, and the results showed that the sidewalk data in the OSM can be used to route navigation. Zhang et al. [37] explored the relationship between road density and road type diversity based on data obtained from China's OSM road network in May 2014, taking 340 prefecture-level cities in China as its study area, it is concluded that the OSM road diversity reflects the demand and value of road-related geographic information and it also reflects the interests of users towards employing the OSM geographical information; Goetz [38] used the points of interest data in the OSM to focus on the detailed display in 3D city modeling. Wang and Zipf [39] used an algorithm to extract the building information in the OSM data for modeling, and the building interior details can be displayed by using the proposed method. In the study of path navigation, Bergman and Oksanen [40] took the OSM data and mobile sport tracking data as research objects, the hidden Markov model (HMM) based as a research method, pointed out that the OSM data has feasibility in bicycle path navigation. In terms of geographic mapping, Rosina et al. [41] took Slovenia and Austria as research objects, and added the OSM data to the Copernicus imperviousness layer to improve the population distribution map, drawing methods of the two countries. The experimental 
result showed that the total error is reduced after adding the OSM data for auxiliary processing, and the addition of the OSM data has certain improvement effects; Zhao et al. [42] studied the evolution of the OSM road network in Beijing from four aspects. Through the experimental analysis, they believed that the development of the OSM road network in Beijing was significantly related to the number of volunteers, and the growth of the OSM road network was very similar to the development process of the real road network. Dingil et al. [43] used the OSM to estimate and analyze the passenger transport energy per person per year of 57 cities, distributed over 33 countries, the results indicating that high private car mode share is a main cause for the high transport energy usage of such cities.

From the above application research on OSM, it is apparent that using OSM data to do research has become more widespread. In this paper, we aim to focus on developing an economic development evaluation for 85 Chinese cities by using OSM spatial metric road network density. The main purpose is to explore the application of the OSM to evaluate the urban economic development of Chinese cities, and take the OSM road network density as a spatial metric to evaluate the level of urban economic development which is measured by the municipal GDP. In our experiment, we selected 85 cities to verify the proposed method, the results show that the correlation between the OSM road network density and municipal GDP are significant. As a result, it is feasible to predict the level of urban economic development by using the OSM road network density.

This paper is organized as follows: the data sources and basic methods are introduced in Sections 2 and 3, respectively. Experimental results and analysis are reported in Section 4. Conclusions are drawn in Section 5.

\section{Study Areas and Data Source}

\subsection{Study Areas}

Since the reform and reopening in 1978, China's urbanization level has continuously improved. As the pioneer area of China's economy development, coastal cities and provincial cities have a higher urbanization rate, which has exceeded $60 \%$ in 2017 [43]. This is because eastern coastal and provincial cities have comparative advantages in resource adsorption, innovation, transportation, and so on, making them leaders in China's overall economic and social development [43]. Since eastern coastal and provincial cities are the pioneers of China's economic and urbanization development, the open-up policy, new technical innovation, and adjustment of input structure methods has improved the urbanization efficiency of China [44,45].

In this paper, we selected a total of 85 cities in China. Among the 85 cities, there were a total of 62 eastern cities, 12 central cities, and 11 western cities. In addition, among the 85 cities, the study included a total of 27 provincial cities and 4 municipalities.

\subsection{Data Collection}

There are three main types of data: OSM road network, municipal GDP, and urban area in each selected city. More details about data sources and data formats are as follows.

\subsubsection{OSM Road Network}

Currently, OSM is one of the most successful and popular VGI projects, and has achieved tremendous development. Until now, there are more than six million registered members in the world, and more than six billion nodes in the OSM database [26], and a lot of research on OSM. Because OSM data are collected through crowdsourcing, the quality of OSM has been often discussed, and usually evaluated based on its quality with authority data. Haklay [46] was the first researcher who analyzed and investigated the data quality of the OSM road network for England, UK. Since then, many researchers have analyzed the data quality of OSM for Germany [47,48], France [49], and China [50]. Luo et al. [50] selected three large, medium, and small cities in China, and compared the length integrity of the OSM road network with the Baidu road network, and Google road network. They indicated that the length 
integrity of the OSM road network is basically consistent with Baidu's road network and the Google road network, and the length integrity of the OSM road network is better than Baidu's road network, and the Google road network in some regions. Hecht et al. [51] measured the completeness of the OSM data on buildings by comparing them with official survey data. It is clear from their research that the OSM building data in urban areas, particularly near the town center, achieve a much higher level of completeness. Singh Sehra et al. [52] introduced a comprehensive review of the assessment of OSM data. Some researchers indicated that OSM has a higher location accuracy, completeness, etc., data quality characteristics in urban areas $[48,53]$. Because, most urban areas with a higher population density inherit larger numbers of contributors, who influence the quantity and quality of the collaboratively crowdsourced OSM objects [45-53]. Therefore, in this paper, we use the urban road network of the OSM to calculate the road network density for 85 Chinese cities.

The OSM road network is downloaded from the OSM website (http://download.geofabrik.de/), which is the ESRI Shapefile. In addition, the projected coordinate system used is the Universal Transverse Mercator (UTM) coordinate system. In this paper, data were collected and downloaded from 2014 to 2018. The OSM road network has about 20 road classes such as cycle way, footway, motorway, residential, primary, and secondary, etc.

\subsubsection{Municipal Gross Domestic Product}

Over the past 40 years, China's economic reform has been successful, becoming one of the most important economic power engines around the world, and the second largest economy measured by GDP. China's rapid economic growth has largely depended on abundant use of natural resources, low-cost investment, and labor with support of a high saving rate, and government policies have also played an important role in promoting infrastructure construction [54]. In recent years, China's economic growth rate has fallen from the double-digit rate from $5 \%$ to $7 \%$. China's economy has entered "The New Normal Economy". There are three main characteristics of The New Normal of China's Economy: (a) a shift from high growth rates to medium-high growth rates; (b) an on-going process of optimizing and upgrading the economic structure, and narrowing the urban-rural gap, with higher personal income as a share of GDP, and an increasing number of people benefiting from economic development; and (c) a transition from growth driven by input and investment to one driven by innovation. These characteristics and measures can promote the steady growth of the Chinese economy, enhance development potential, and further unleash market vitality [55]. No matter if China's economy is in the double-digit growth rate or the current "new normal economy" medium-high growth rate, the GDP is an index used to describe the economic development level of a city, and the efficient transportation system, population, technology, etc., have a positive impact on GDP. Among the 85 selected cities, a total of 5 first-grade cities, 31 second-grade cities, and 49 third-grade cities were identified (https://www.yicai.com/news/5293378.html). Overall, the GDP and urbanization rate of the first-grade cities are higher than the second-grade cities, and the GDP and urbanization rate of the second-grade cities are higher than the third-grade cities.

In our research, municipal GDP data are collected from the National Bureau of Statistics (http: //www.stats.gov.cn/), data on GDP are from 2014 to 2018, and municipal GDP unit is in trillion CNY.

\subsubsection{Exploring the Urban Area of Each Selected City}

The study scope analyzed a total of 85 main urban areas. The study applied the unit of area square kilometers. Take Shanghai for example, the scope of the main urban area is extracted from the Shanghai Bureau of Planning and Natural Resources Department (http://ghzyj.sh.gov.cn/). Figure 1 shows the location and the municipal GDP in 2018 of the selected 85 cities. 


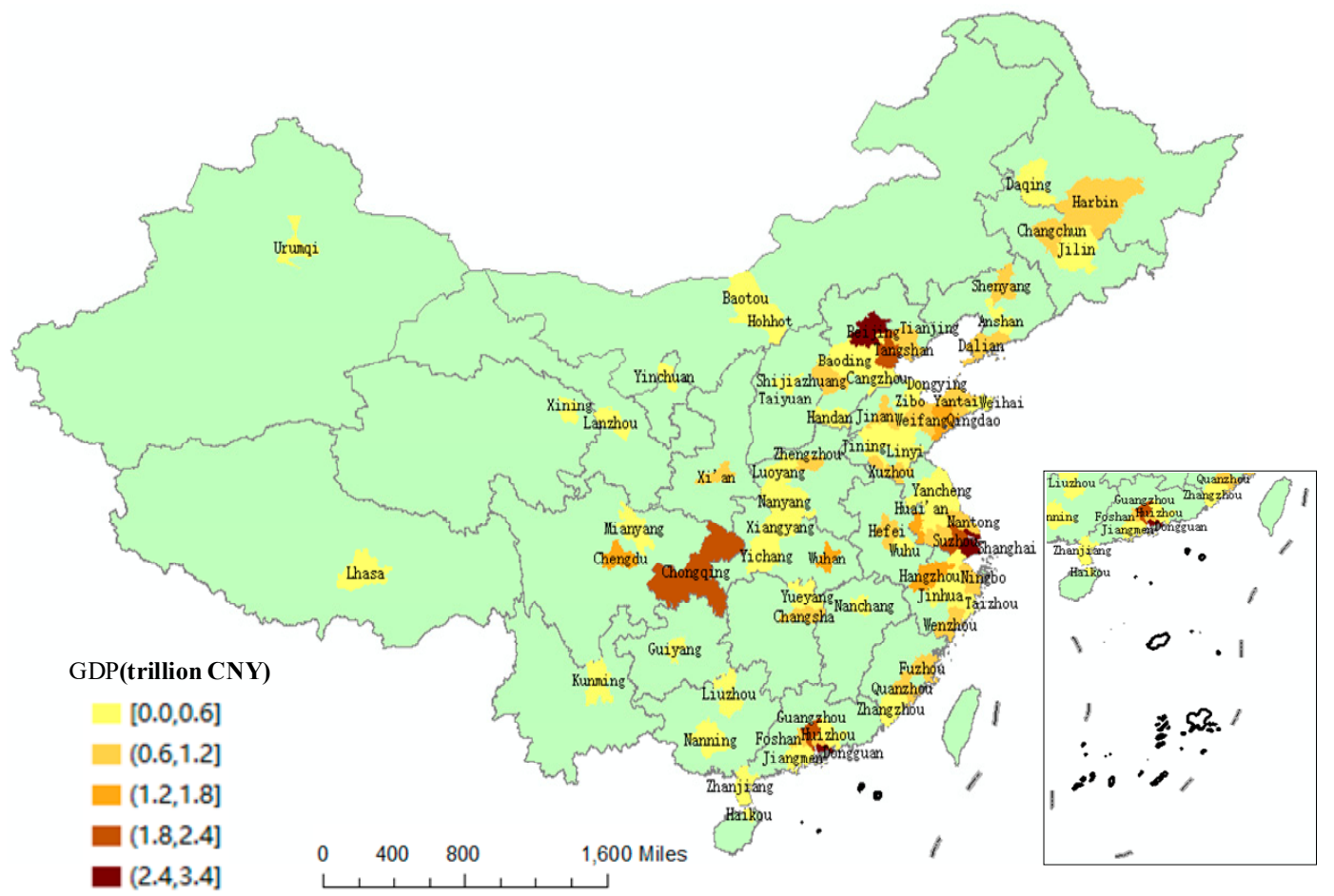

Figure 1. Study research area and gross domestic product (GDP) in 2018.

\section{Methodology}

Regression analysis is one of the most commonly statistical analysis methods used to describe the correlation between independent variables and dependent variables [56]. In our paper, we used a regression model to study the correlation between the OSM road network density and the municipal GDP, and employed the OSM road network density as a spatial metric to evaluate the level of urban economic development of cities. In this section, we do not describe the details of the regression model, but only introduce the calculation method of the OSM road network density.

\section{Calculating the OSM Road Network Density of a City}

The road network density is an important index for the evaluation of regional road traffic [57-59]. The OSM road network density comprises of geographical information that reflect a real-world road network, and an index for assessing the quality of OSM geographic data. In this study, we calculated the OSM road network density of 85 Chinese cities [60,61]:

$$
D_{i}=L_{i} / A_{i} i \in[1,2,3, \ldots, 85],
$$

where one main urban area is $i$, the OSM road network density in the main urban area $i$ is $D_{i}$, the OSM road network length for the main urban area $i$ is $L_{i}$, and the area of the main urban area $i$ is $A_{i}$.

Figure 2 shows the OSM road network in three different grades based on city. The blue polylines are the OSM road network in 2018. The red polylines are the OSM road networks in 2014. Figure 1 shows the cities of Beijing, Shanghai, and Guangzhou as first-grade cities. Compared to the cities of Nanjing, Wuhan, and Chengdu with second-grade cities, and the cities of Guiyang, Haikou, and Lanzhou with third-grade cities, these cities have different levels of economic development and OSM road network density. 

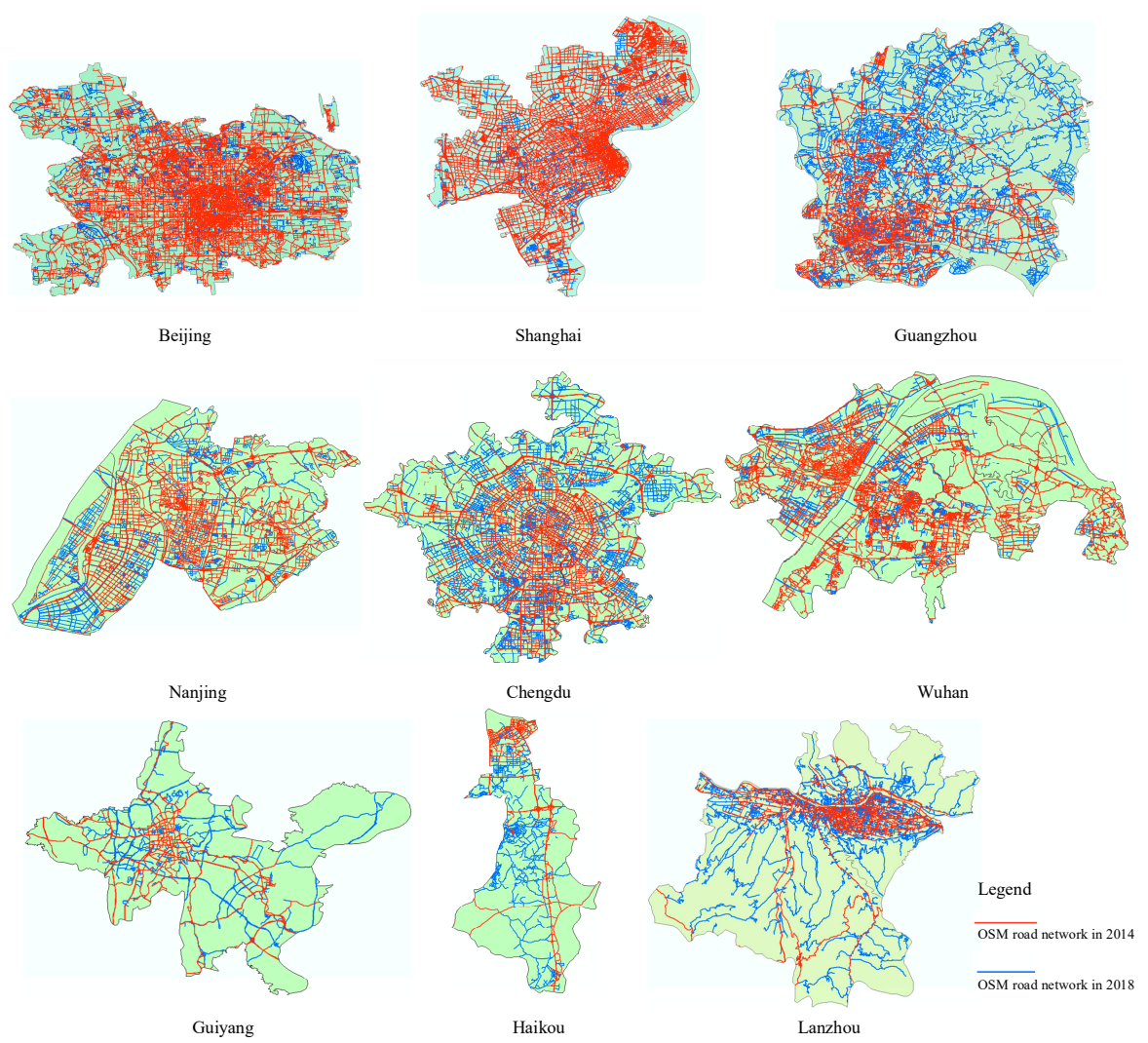

Figure 2. The OpenStreetMap (OSM) road network with three different grades in Chinese cities.

\section{Results and Analysis}

\subsection{Fit Analysis}

In this paper, we used Equation (1) to calculate the OSM road network density from 2014 to 2018, then applied the OSM road network density data from 2014 to 2017 as the independent variable, and the municipal GDP from 2014 to 2017 as the dependent variable. Moreover, the regression models of the 85 Chinese cities were obtained using the unary linear regression model, and then applied the OSM road network density and the municipal GDP data in 2018 to validate the regression model.

The OSM road network density, the municipal GDP, the regression models, and the coefficient of determination $\left(R^{2}\right)$ of the 85 Chinese cities from 2014 to 2017 are shown in Table A1 (Appendix A), the statistics of $R^{2}$ are shown in Figure 3. Among all the cities, the maximum value of $R^{2}$ is Guangzhou, and its $R^{2}$ is 0.999; the minimum value of $R^{2}$ is Hohhot, and its $R^{2}$ is 0.0005 . The distribution of coefficient of determination is shown in Figure 4.

In this paper, we also used the OSM road network density and population data from 2014 to 2017 as the independent variables, the municipal GDP from 2014 to 2017 as the dependent variable, the regression models of 85 Chinese cities were obtained using a binary linear regression model, and then used the OSM road network density and the municipal GDP data in 2018 to validate the same regression model.

The statistics of $R^{2}$ are shown in Figure 5, and the distribution of coefficient of determination is shown in Figure 6. Among all the selected cities, the maximum value of $R^{2}$ is Taizhou, its $R^{2}$ is 0.9999 . The minimum value of $R^{2}$ is Baotou, its $R^{2}$ is 0.3353 . In this regression model, the $R^{2}$ of Guangzhou is 0.9996 , and the $R^{2}$ of Hohhot is 0.4842 . The distribution of coefficient of determination is shown in Figure 6. In addition, we can see that the $\mathrm{R}^{2}$, which is calculated by the OSM road network density and population, is higher than the $\mathrm{R}^{2}$, which is calculated by the OSM road network density and is 
consistent with reference [24,62]. Fan and Chan-Kang [24], Savaş [62] indicated that there is a high correlation in cities with road investments, population, and economic growth.

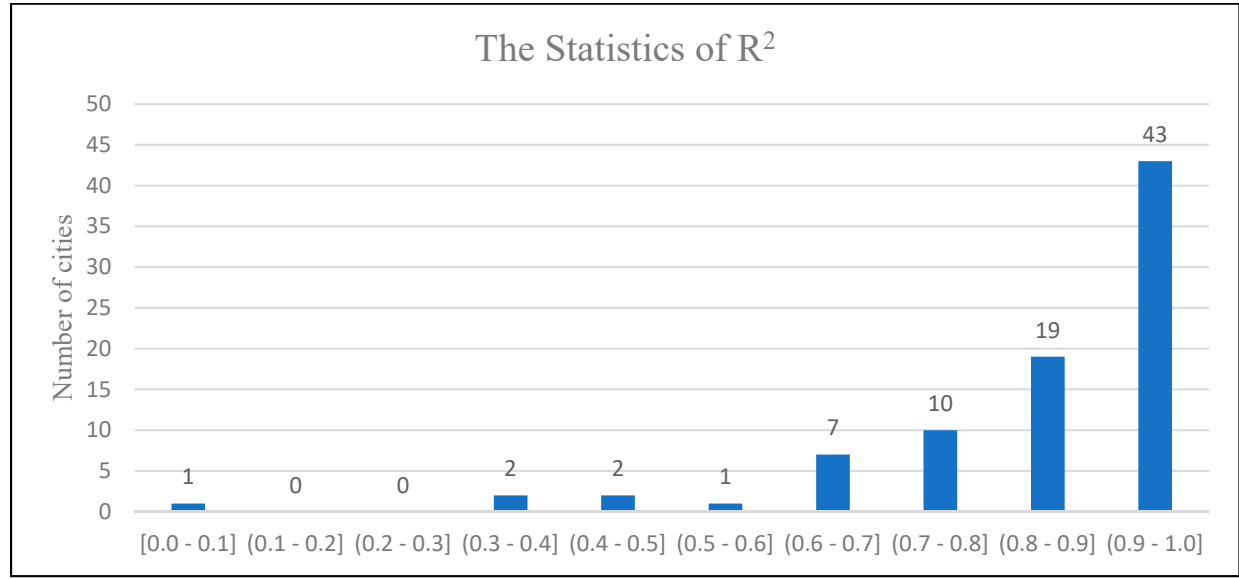

Figure 3. Statistics of $\mathrm{R}^{2}$ calculated by the OSM road network density.

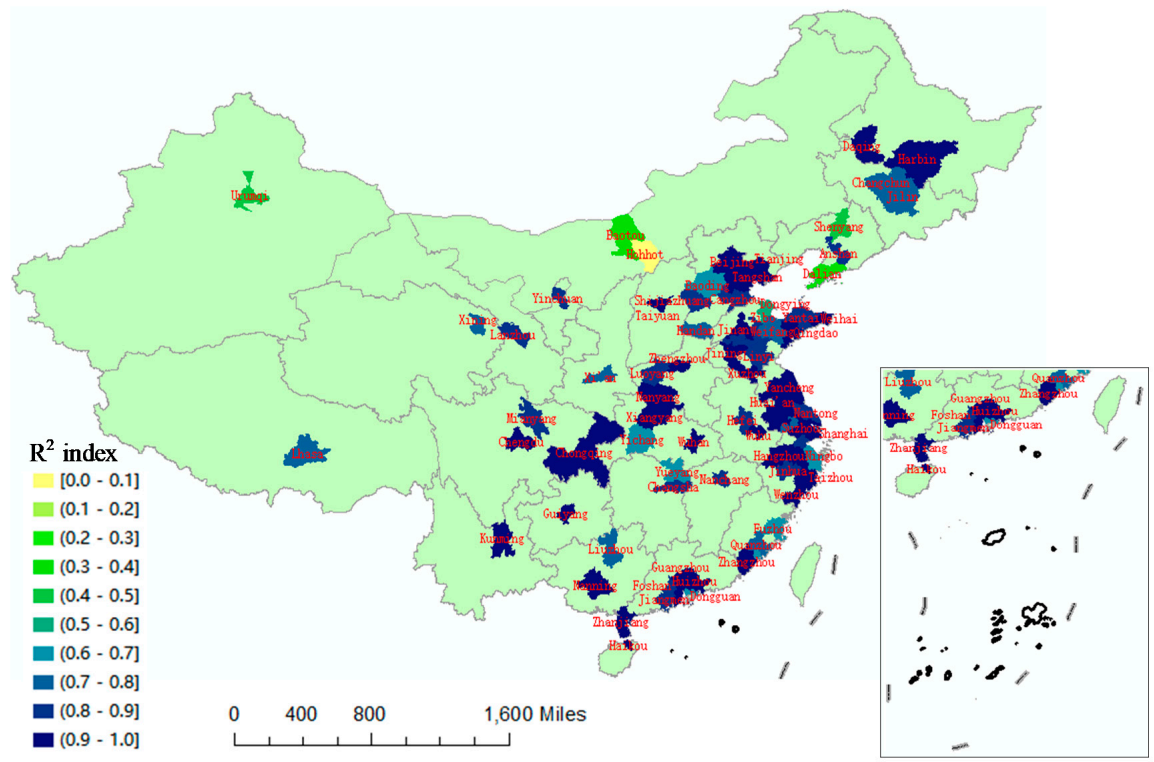

Figure 4. Distribution of $R^{2}$ calculated by the OSM road network density.

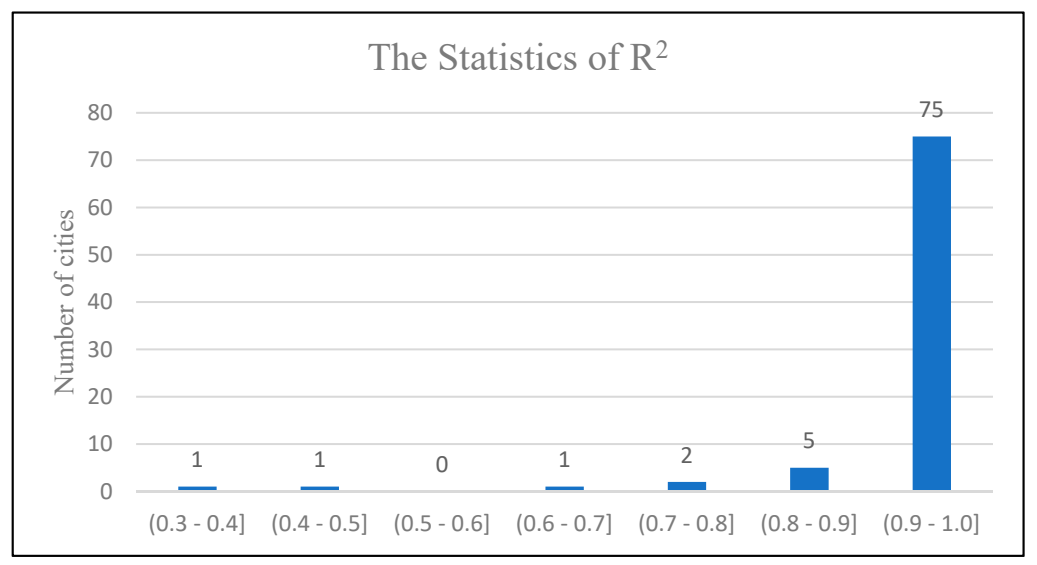

Figure 5. Statistics of $\mathrm{R}^{2}$ calculated by the OSM road network density and population. 


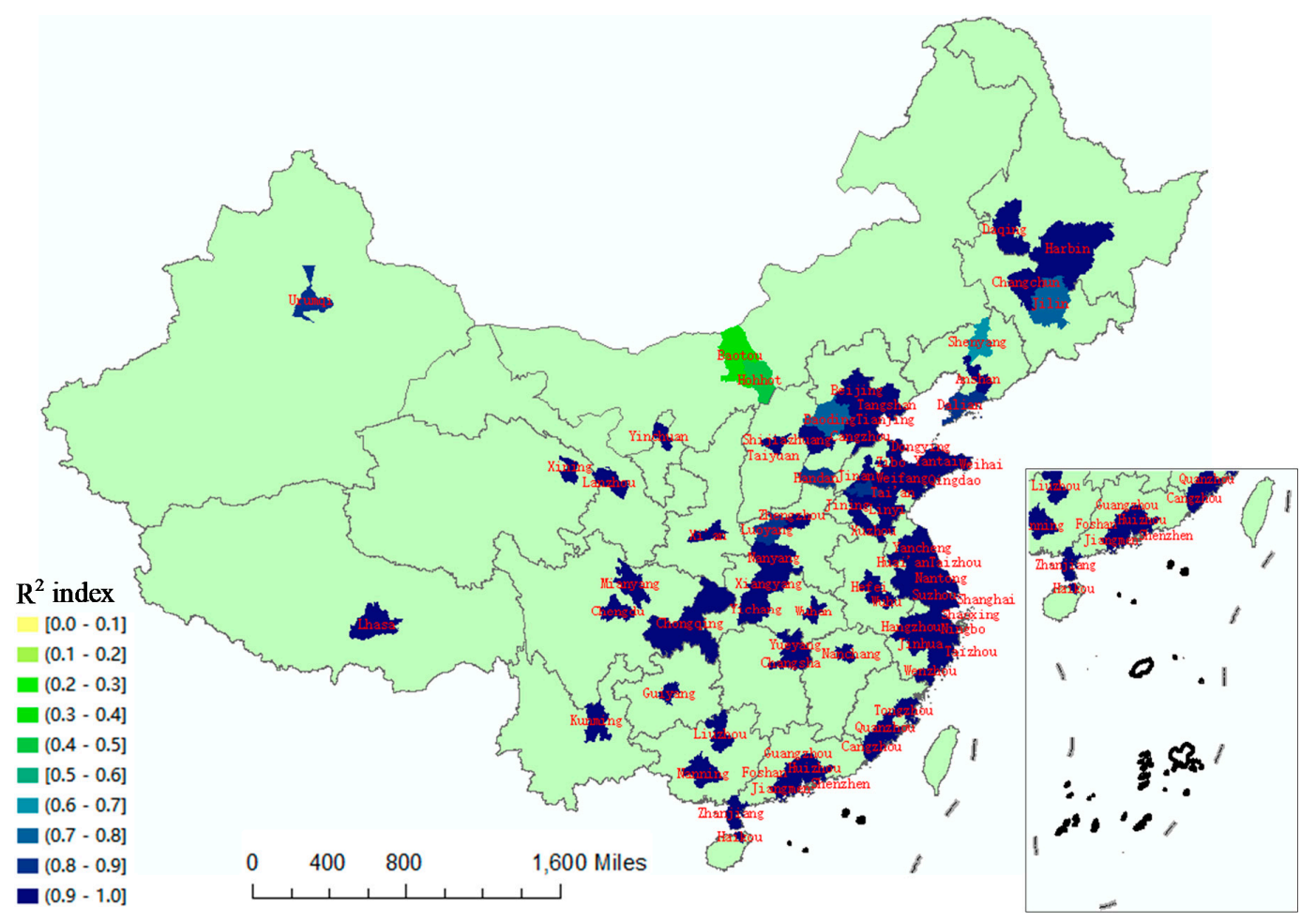

Figure 6. Distribution of $\mathrm{R}^{2}$ which is calculated by the OSM road network density and population.

Figure 3 shows a total of 72 cities with significant correlation with coefficient of determination $\mathrm{R}^{2}$ above 0.7 , accounting for $84.71 \%$. These 72 cities experienced rapid economic development during the four years from 2014 to 2017, and with their municipal GDP increasing steadily year by year; 5 cities with coefficient of determination $R^{2}$ below 0.5 , they are Shenyang, Urumqi, Dalian, Baotou, and Hohhot, respectively, and their $R^{2}$ are $0.499,0.483,0.342,0.303$, and 0.0005 , respectively. The municipal GDP statistical data and the OSM road network density for these five cities are shown in Tables 1 and 2. It can be seen that the municipal GDP for these five cities does not increase year by year, but the density of the OSM road network increases year by year.

Table 1. The Chinese municipal GDP (trillion CNY) statistical results of five cities.

\begin{tabular}{cccccc}
\hline City & GDP (2014) & GDP (2015) & GDP (2016) & GDP (2017) & GDP (2018) \\
\hline Shenyang & 0.709871 & 0.728000 & 0.546001 & 0.586497 & 0.62924 \\
Urumqi & 0.246147 & 0.263164 & 0.245898 & 0.274382 & 0.309962 \\
Dalian & 0.765558 & 0.773164 & 0.68102 & 0.73639 & 0.76685 \\
Baotou & 0.363631 & 0.378193 & 0.386763 & 0.275303 & 0.29518 \\
Hohhot & 0.289405 & 0.309052 & 0.317359 & 0.274372 & 0.29035 \\
\hline
\end{tabular}

Table 2. The OSM road network density of the five cities.

\begin{tabular}{cccccc}
\hline City & OSM RND (2014) & OSM RND (2015) & OSM RND (2016) & OSM RND (2017) & OSM RND (2018) \\
\hline Shenyang & 2.014 & 2.150 & 2.203 & 2.292 & 2.449 \\
Urumqi & 1.472 & 1.489 & 1.549 & 1.917 & 1.676 \\
Dalian & 1.750 & 1.838 & 0.852 & 0.900 & 1.851 \\
Baotou & 0.601 & 0.629 & 0.860 & 0.870 & 2.441 \\
Hohhot & 0.567 & 0.656 & 0.399 & 0.962 \\
\hline
\end{tabular}

Note: OSM RND represents the OSM road network density.

Hohhot shows the minimum coefficient of determination, and the coefficient of determination is 0.0005. We found that the GDP of Hohhot decreased from 317.359 billion CNY in 2016 to 274.372 billion CNY in 2017. However, the density of the OSM road network in the main urban area gradually 
increased from 2014 to 2017. More specifically, in 2016, with an increase of 0.204 compared with 2015, which is much higher than other years. Baotou and Hohhot, which are located in the Inner Mongolia Autonomous Region of China, have similar patterns. In 2017, the GDP of Baotou was 275.303 billion CNY, a decrease of 111.46 billion CNY from 386.763 billion CNY in 2016. The density of the OSM road network in the main urban area increased from 0.629 in 2015 to 0.852 in 2016, an increase of 0.22 , which is much higher than changes in other years.

\subsection{Validation of the Model}

In order to validate the regression model obtained by the OSM road network density in the above section, we used the real municipal GDP of 85 Chinese cities in 2018 to validate the regression model. The statistical results of the absolute residuals and relative residuals when using the OSM road network density are shown in Table A2, Figure 7, and Figure 8, respectively. The distribution of absolute residual and relative residual results when using the OSM road network density is shown in Figures 9 and 10, respectively.

The calculation method of absolute residual $\left(R_{\text {absolute }}\right)$ and relative residual $\left(R_{\text {relative }}\right)$ is as follows:

$$
\begin{gathered}
R_{\text {absolute }_{\text {e }}=\text { Predictive }_{i}-\text { Real }_{i} i \in[1,2,3, \ldots, 85],} \\
R_{\text {relative }}=\frac{\left(\text { Predictive }_{i}-\text { Real }_{i}\right)}{\text { Real }_{i}} \times 100 i \in[1,2,3, \ldots, 85],
\end{gathered}
$$

where one main urban area is $i$, the predictive GDP of the main urban area $i$ in 2018 is Predictive $_{i}$, the real GDP of the main urban area $i$ in 2018 is Real $_{i}$.

At the same time, we validated the regression model obtained by using the OSM road network density and population, we also used the real municipal GDP of 85 cities in 2018 to validate the regression model, and the statistical results of the absolute residuals are shown in Figures 11 and 12, respectively. The distribution of residual results is shown in Figures 13 and 14, respectively.

We calculated the difference between the residual, which is obtained by using the OSM road network density, and population. The statistical results of the differences are shown in Figure 15, and the distribution of the differences are shown in Figure 16. The results show 69 cities with residual differences between -0.1 and 0.1 , accounting for $81.18 \%$; a total of 76 cities with residual differences between -0.2 and 0.2 , accounting for $89.41 \%$. Overall, the forecasting results by using the OSM road network density are found to have similar characteristics in the forecasting results when using the OSM road network density and population. This shows that the OSM road network density can be used as a spatial metric to evaluate the level of urban economic development in cities.

Considering that the main purpose of this paper is to study whether the OSM road network density can be used as a spatial metric to evaluate the level of urban economic development, the following discussion will focus on forecasting results obtained by using the OSM road network density.

As shown in Figure 7 and Table A2, there are a total of 50 Chinese cities that have negative absolute residuals, and 35 cities with positive absolute residuals. The largest positive absolute residual is Chongqing, with a value of the absolute residual of 0.444 ; the smallest negative absolute residual is Shenzhen, with a value of the absolute residual of -0.2817 . The absolute residuals of 44 cities are between -0.1 and 0.0 , accounting for $51.76 \%$, and the absolute residuals of 27 cities are between 0.0 and 0.1 , accounting for $31.76 \%$. The absolute residuals of 71 cities are between -0.1 and 0.1 , accounting for $85.53 \%$. The absolute residuals of 4 cities are between -0.2 and -0.1 , accounting for $4.71 \%$. The absolute residuals of 4 cities are between 0.1 and 0.2 , accounting for $4.71 \%$. The absolute residuals of 79 cities are between -0.2 and 0.2 , accounting for $92.94 \%$. 


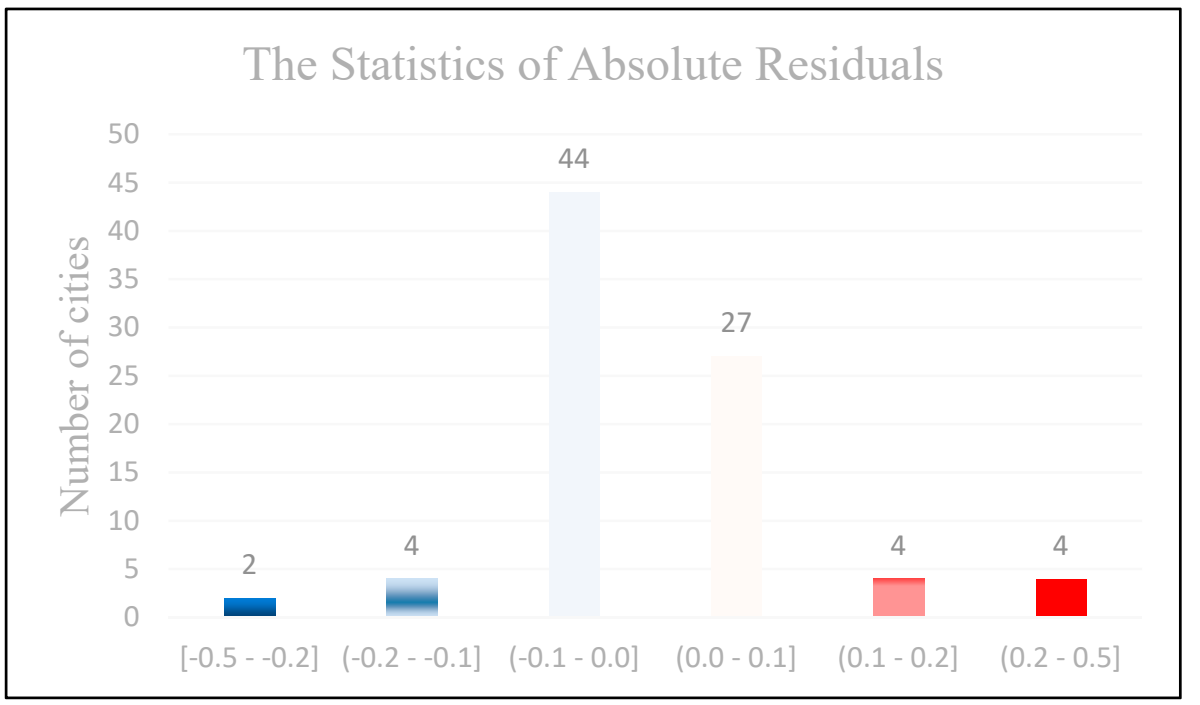

Figure 7. The statistical result of the absolute residuals by using the OSM road network density.

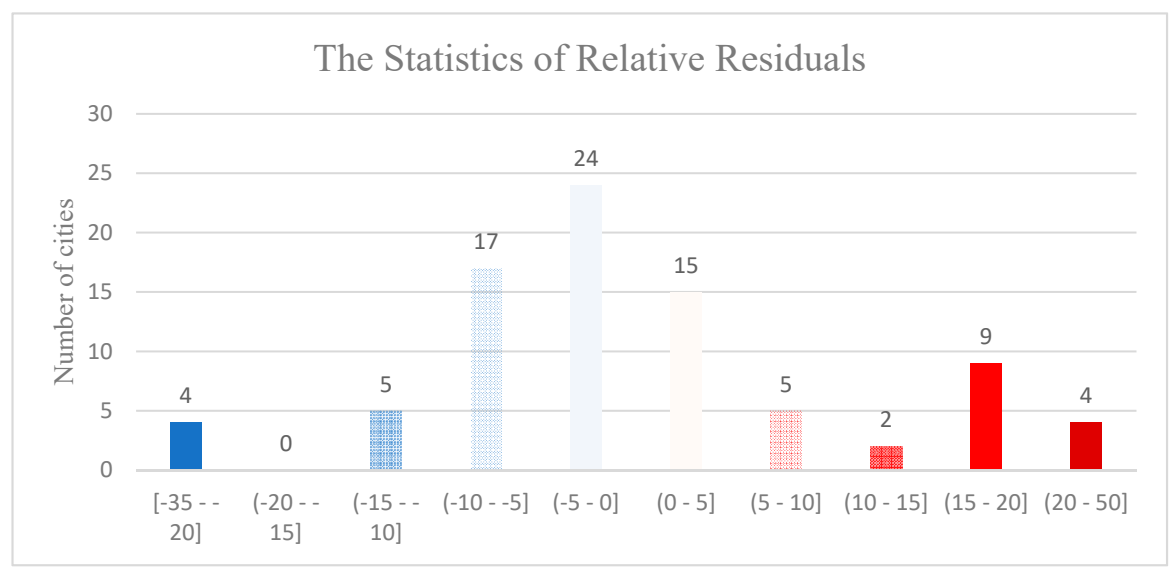

Figure 8. The statistical result of the relative residuals by using the OSM road network density.

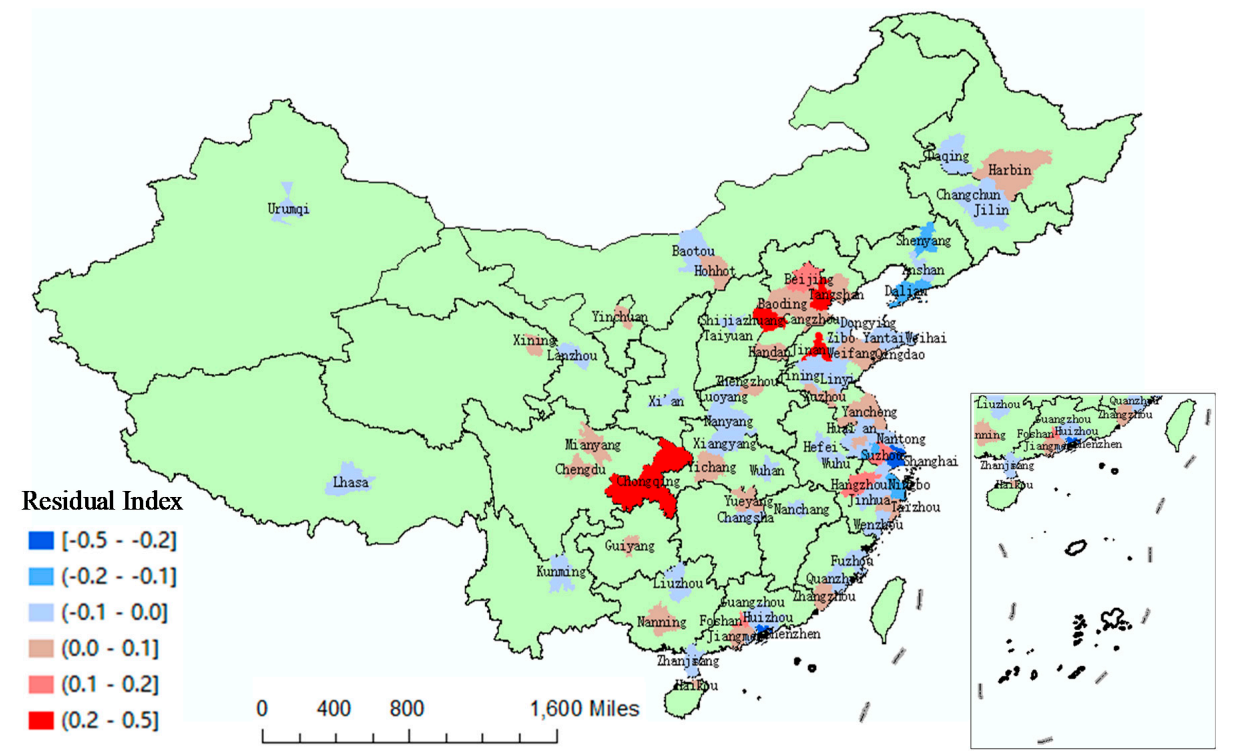

Figure 9. Distribution of the absolute residuals of 85 Chinese cities by using OSM road network density. 


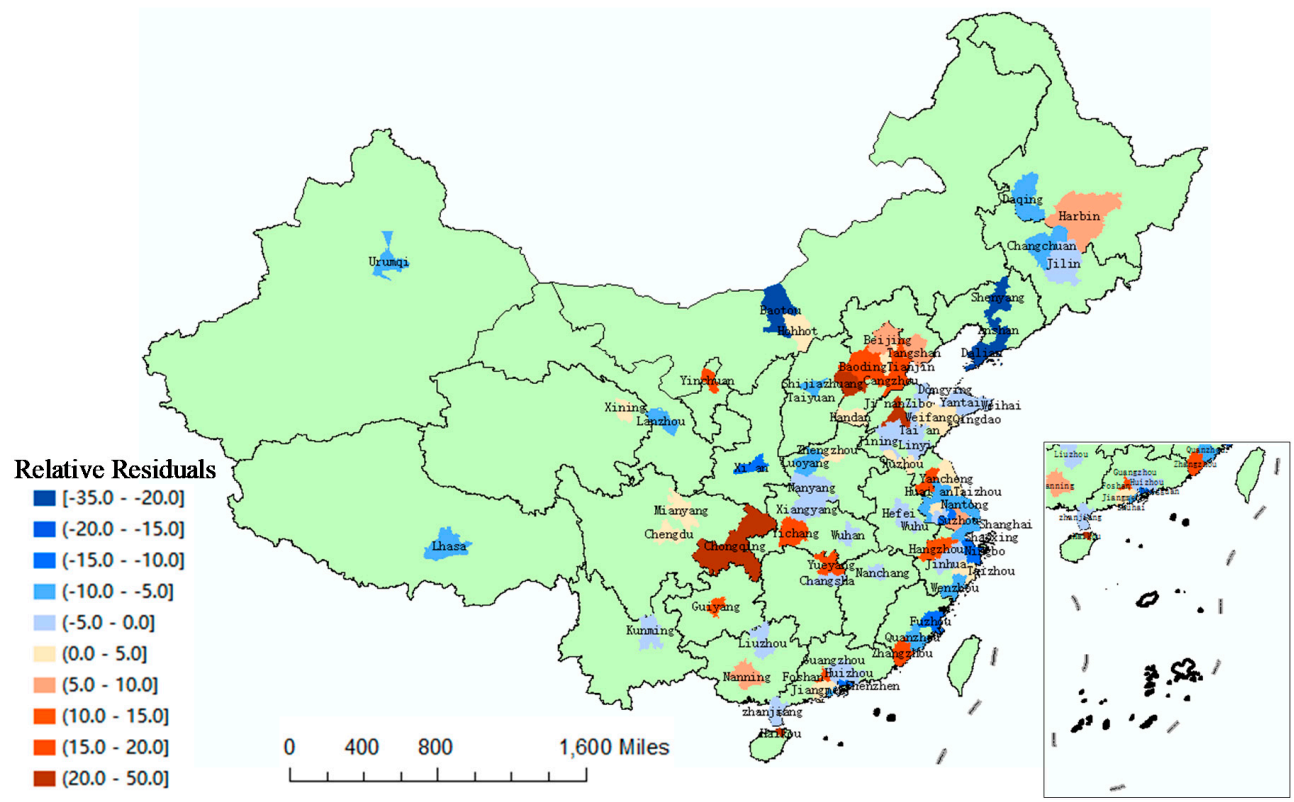

Figure 10. Distribution of the relative residuals of 85 Chinese cities by using OSM road network density.

As shown in Figure 8 and Table A2, there are a total of 50 Chinese cities that have negative relative residuals, and 35 cities with positive relative residuals. The smallest negative relative residual is Anshan, with a relative residual of -34.6088 , and the largest positive relative residual is Shijiazhuang, with a value of the relative residual of 47.8711 . The relative residuals of 41 cities are between -10 and 0.0 , accounting for $48.24 \%$, and the relative residuals of 20 cities are between 0.0 and 10, accounting for $23.53 \%$. The relative residuals of 61 cities are between -10.0 and 10.0 , accounting for $71.76 \%$. The relative residuals of 77 cities are between -20.0 and 20.0, accounting for $90.59 \%$.

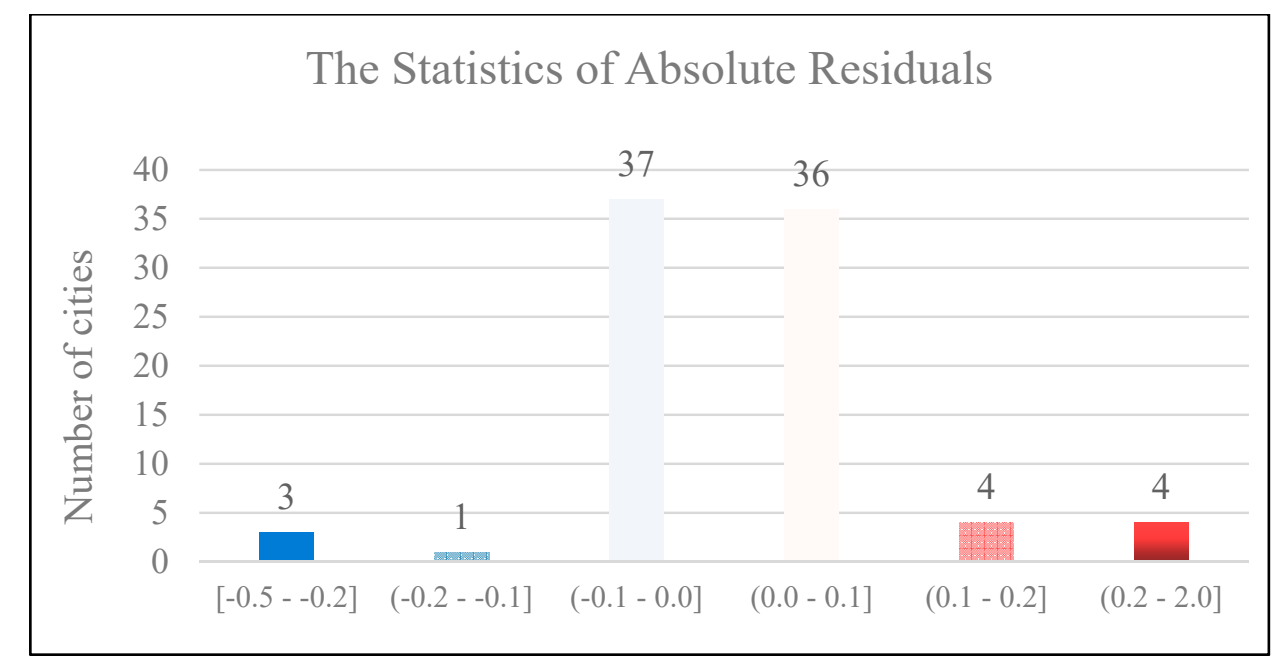

Figure 11. The statistical result of the absolute residuals by using OSM road network density and population.

Results indicate that the regression models obtained from the above section have a high prediction accuracy, and the OSM road network density can be used as a spatial metric to forecast the municipal GDP. In order to directly discuss the difference between the predicted GDP in 2018 and GDP in 2018, the following discussion is based on the absolute residuals in Figure 7 and Table A2. 


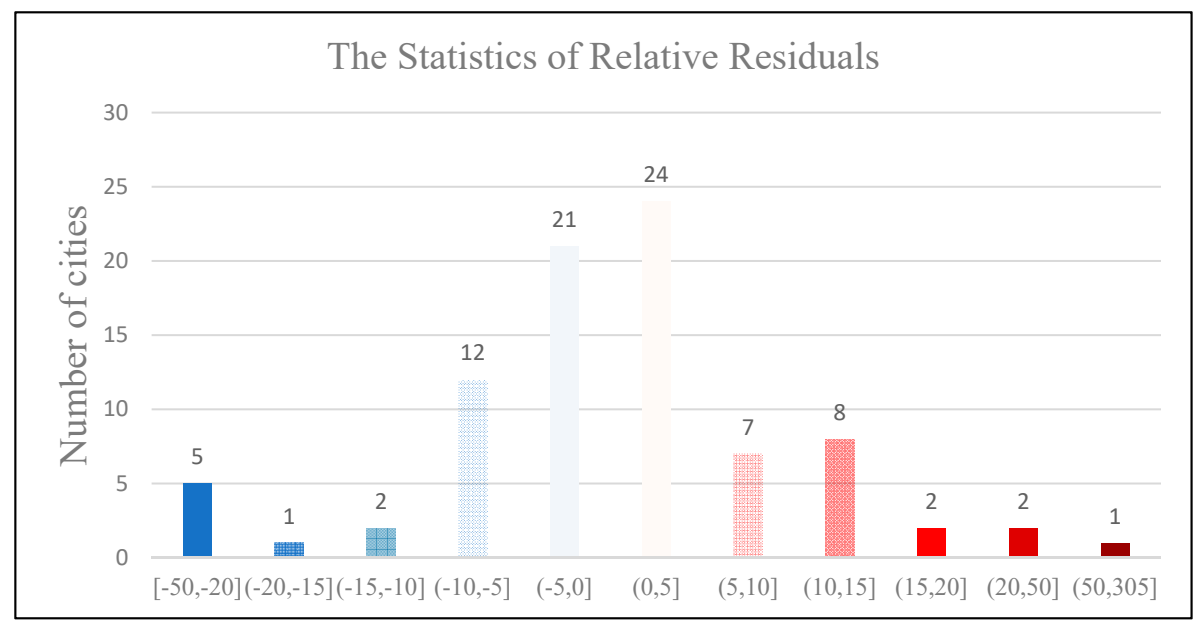

Figure 12. The statistical result of the relative residuals by using OSM road network density and population.

The largest positive value of residual is Chongqing, the value of residual is 0.444 . Chongqing is located in the southwest of China, and is the only municipality in the southwest of China, its total area is 82,400 square kilometers, and its main urban area is 7220 square kilometers. The municipal GDP and OSM road network density from 2014 to 2018 are shown in Tables A1 and A2. From 2014 to 2017, the municipal GDP of Chongqing increased year by year, the average annual municipal GDP growth of Chongqing is 172.084 billion CNY. However, the municipal GDP growth in 2018 is 93.824 billion CNY, far lower than the average annual municipal GDP growth in the previous 3 years. The OSM road network density growth in 2018 is 0.38 , and the average OSM road network density growth is 0.13 , different from the municipal GDP growth change in 2018, the OSM road network density growth in 2018 is much higher than the average OSM road network density growth during the previous 3 years, and the inconsistent trends in municipal GDP growth and OSM road network growth have resulted in excessive forecast residual.

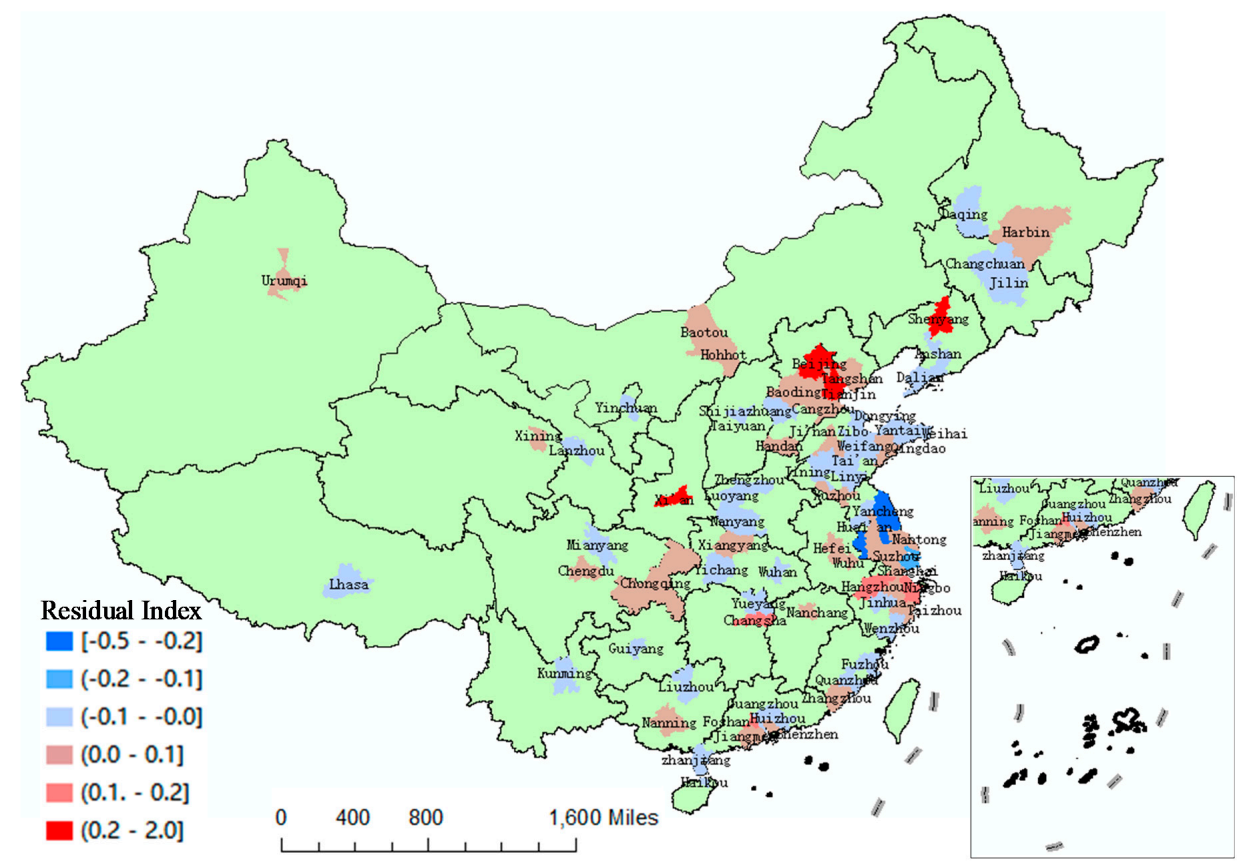

Figure 13. Distribution of 85 Chinese cities' absolute residuals using OSM road network density and population. 


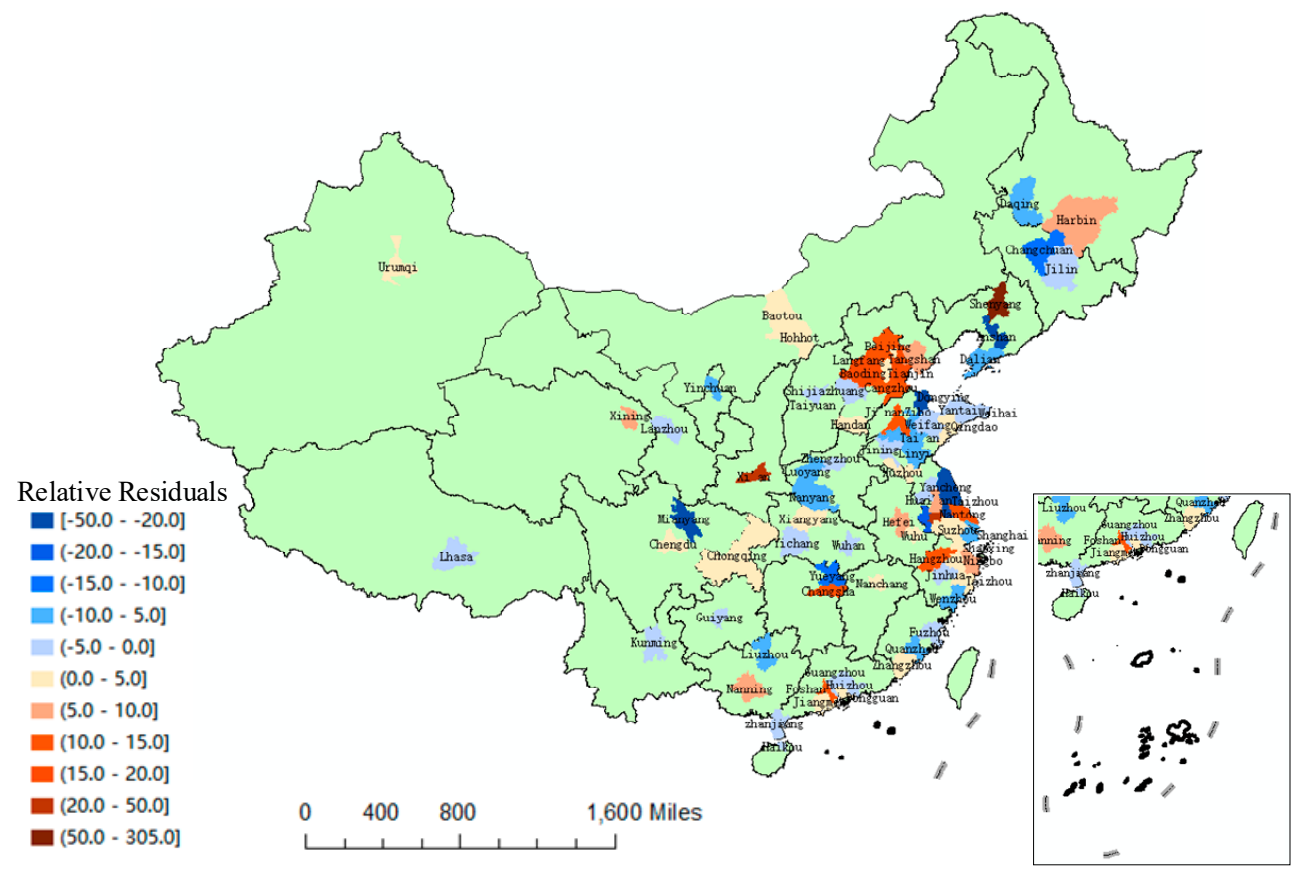

Figure 14. Distribution of 85 Chinese cities' relative residuals using OSM road network density and population.

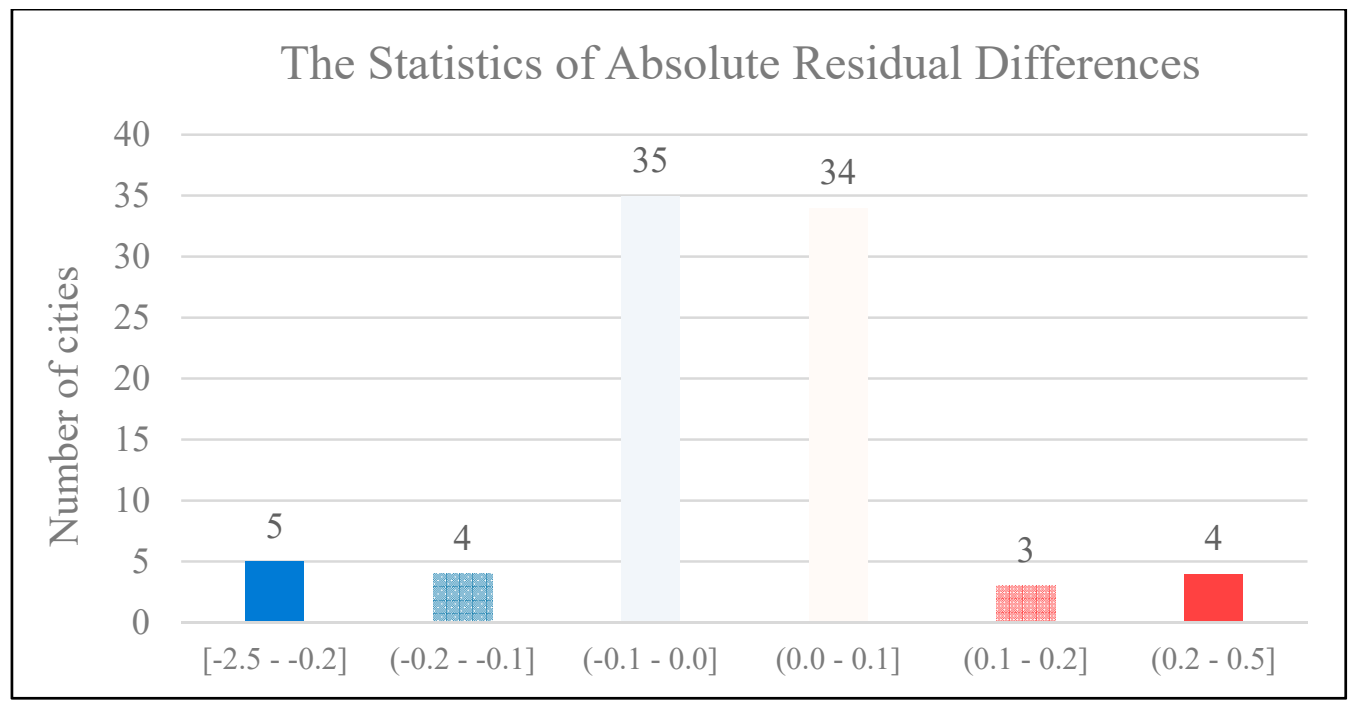

Figure 15. Statistical result of the difference between two residuals.

Tianjin has the second largest residual, the value of the residual is 0.3149 . Tianjin is a municipality located in the north of China, total area is 11,900 square kilometers, and the main urban area is 1007 square kilometers. From 2014 to 2018, the total municipal GDP of Tianjin increased year by year, but the municipal GDP growth varied greatly. The municipal GDP growth in 2018 is 260.45 billion CNY, compared to the average GDP growth of 94.075 billion CNY. As a result, the municipal GDP growth in 2018 is much lower than the average GDP growth from the previous three years. However, the OSM road network density of Tianjin is increasing quickly, more specifically in 2018, the OSM road network density growth is 0.89 , and the average OSM road network density growth is 0.26 , the OSM road network density growth in 2018 is much higher than the average OSM road network density growth during the previous 3 years, and these factors finally caused the excessive forecast residuals. 


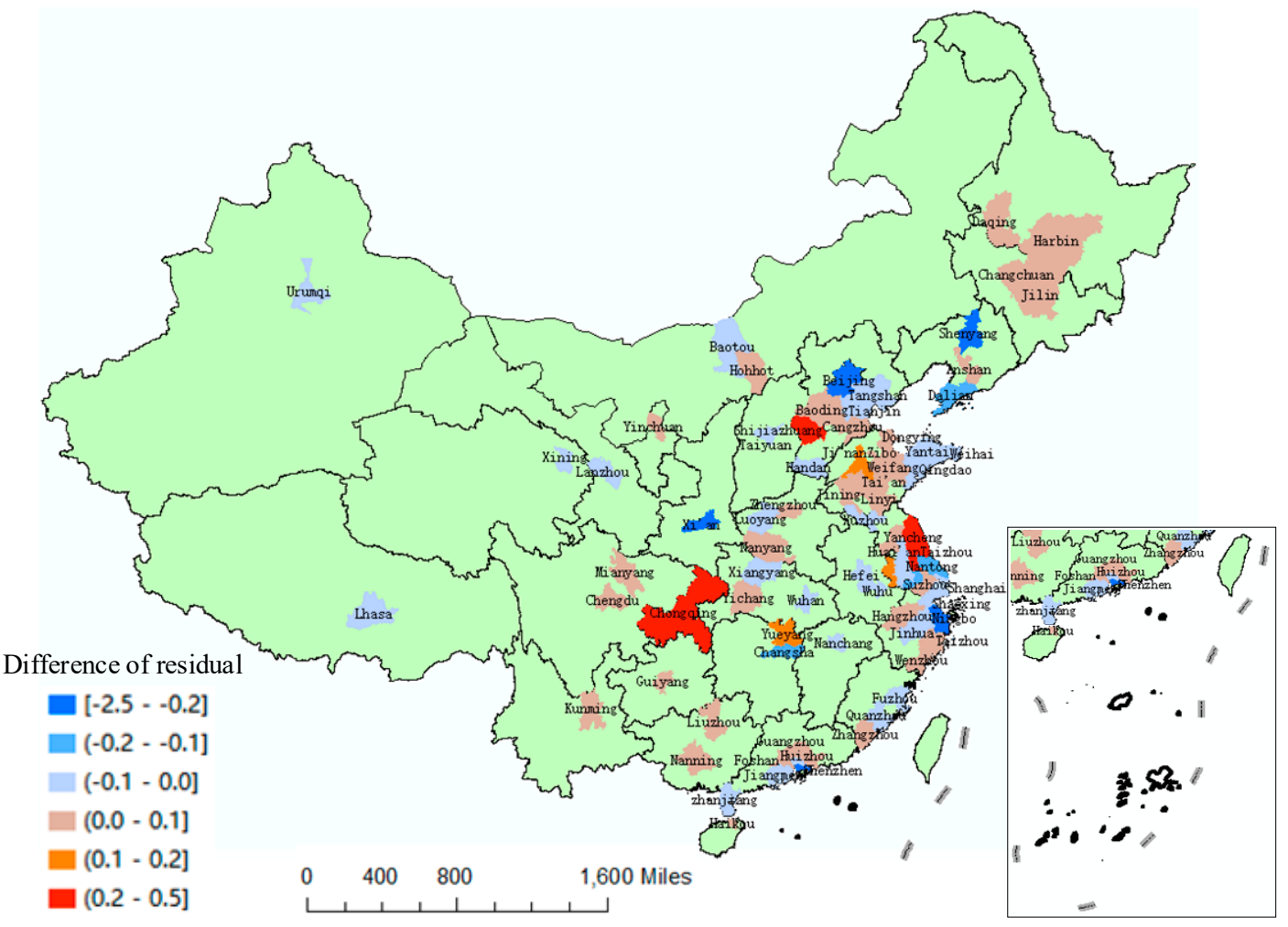

Figure 16. Distribution of absolute residual differences.

On the contrary, Shenzhen has the smallest negative residual, the value of the residual is -0.2817 . Shenzhen is an important special economic development zone in the south of China, its total area is 1997 square kilometers, and the main urban area is 927 square kilometers. Shenzhen's economy is developed with a steady growth from 1.600182 billion CNY in 2014 to 2.4222 billion CNY in 2018 . However, during 2014 to 2017, the annual growth of road density in Shenzhen showed a downward trend, but an annual growth in 2018. Thus, the difference between the variation tendency of the municipal GDP and the variation tendency of the OSM road network density makes the forecast value of the municipal GDP smaller than the real data, which leads to Shenzhen's residual to have the smallest negative residual.

Overall, between the 85 cities, a total of 8 cities were found with absolute residual larger than 0.1 , and 6 cities with absolute residual lower than -0.1 , these 14 cities include Beijing, Shanghai, Shenzhen, Tianjin, Chongqing, Hangzhou, Dalian, Ningbo, Ji'nan, Suzhou, Shenyang, Wuxi, Foshan, and Shijiazhuang. These 14 cities all have characteristic of developed cities. In recent years, the pace of urban construction of these developed cities has increased at a rapid pace, having large populations, which can contribute a lot to the municipal GDP growth. From 2014 to 2018, the changes of municipal GDP are not consistent with the OSM road network density. More specifically, the municipal GDP annual growth for the above 14 cities in 2018 is much lower than that in 2017, but at the same time, the OSM road network density is increasing, which caused a big absolute residual value.

However, when considering the other 71 cities, the absolute residuals are found to be between -0.1 and 0.1. From 2014 to 2018, the municipal GDP growth of these cities did not change drastically, the change trend of the municipal GDP and OSM road network density has similarities, resulting in a smaller absolute residual. Among these 71 cities, most cities are second and third grade cities, these cities were found to have smaller populations. Therefore, to some extent, the analysis of the absolute residual in the paper also confirms that the current economic development strategy of China with a high-speed economic stage to a medium-high-speed economic stage has a relatively 
predicted impact in developed cities, when compared to the second and third grade cities, where the impact is not significant.

\section{Conclusions}

This study focused on using the urban OSM road network density as a spatial metric to evaluate the urban economic development of 85 Chinese cities. The following conclusions are identified in this paper:

(1) The OSM road network density can be used as a spatial metric to estimate and predict the level of urban economic development of cities which is commonly measured by the municipal GDP.

(2) It is feasible to analyze the level of urban economic development of cities by using the OSM road network density. There is a significant correlation between the OSM road network density and the municipal GDP. Results demonstrated a total of 71 Chinese cities with absolute residuals between -0.1 and 0.1 , accounting for $83.53 \%$; and 79 cities with absolute residuals between -0.2 and 0.2 , accounting for $92.94 \%$. There are 61 cities with relative residuals between -10 and 10 , accounting for $71.76 \%$; and there are 77 cities with relative residuals between -20 and 20 , accounting for $90.59 \%$.

(3) In our experiment, the $R^{2}$ is calculated with the OSM road network density and population is higher than the $\mathrm{R}^{2}$. which is calculated by the OSM road network density, but for the residuals, the absolute and relative residuals by using the OSM road network density are found to have similar characteristics as the absolute and relative residuals by using the OSM road network density and population. Among the 85 cities, there are 73 cities with absolute residuals between -0.1 and 0.1 , accounting for $85.88 \%$; and 78 cities with absolute residuals between -0.2 and 0.2 , accounting for $91.76 \%$.There are a total of 64 cities with relative residuals between -10 and 10 , accounting for $75.29 \%$; and there are 77 cities with relative residuals between -20 and 20, accounting for $90.59 \%$.

(4) The development strategy of the Chinese economy is changing from high-speed development to medium-high speed development, these findings are more apparent in economically developed cities, compared to ordinary cities. Moreover, economically developed cities pay more attention to the influence of high technology.

The research in this paper has identified the imperfections found in the method when using the OSM road network density to evaluate and predict the level of urban economic development in Chinese cities. It is evident that the OSM road network density can be used as a spatial metric for predictive analysis and policy making to gain transparency. In the future, we will use the proposed spatial metric to do some related research.

Author Contributions: Methodology, Bo Liu, Yu Shi, Da-Jun Li and Ming-Hsiang Tsou; Software, Yu Shi; Visualization, Yu Shi and Bo Liu; Writing-original draft, Bo Liu, Yu Shi and Yan-Dong Wang; Writing-review and editing, Yan-Dong Wang, Gabriela Fernandez and Ming-Hsiang Tsou. All authors have read and agreed to the published version of the manuscript.

Funding: This work was funded by the National Key Research and Development Program of China (No.2016YFB0501403), The National Natural Science Foundation of China (Nos. 41201395, 416014160), The Key Laboratory of Earth Observation and Geospatial Information Science of NASG (201811), and the China Scholarship Council Foundation of China (No. 201808360267).

Acknowledgments: Thank you to the Center for Human Dynamics in the Mobile Age, Department of Geography, San Diego State University, San Diego, California, USA.

Conflicts of Interest: The authors declare no conflict of interest. 


\section{Appendix A}

Table A1. The statistical results of the municipal GDP, coefficient of determination $\mathrm{R}^{2}$, and regression equation of 85 Chinese cities from 2014 to 2017.

\begin{tabular}{|c|c|c|c|c|c|c|c|c|c|c|c|c|}
\hline \multirow{2}{*}{ No. } & \multirow{2}{*}{ Cities } & \multirow{2}{*}{ Location of the Cities } & \multicolumn{4}{|c|}{ Municipal GDP (trillion CNY) } & \multicolumn{4}{|c|}{ OSM RND Represent the OSM Road Network Density } & \multirow{2}{*}{ Regression Equation } & \multirow{2}{*}{ Coefficient of Determination $\left(R^{2}\right)$} \\
\hline & & & 2014 & 2015 & 2016 & 2017 & 2014 & 2015 & 2016 & 2017 & & \\
\hline 1 & Beijing & Eastern & 2.13308 & 2.29686 & 2.48993 & 2.80004 & 4.958224 & 5.141546 & 5.357883 & 5.499061 & $y=1.174 x-3.721$ & 0.9515 \\
\hline 2 & Shanghai & Eastern & 2.356094 & 2.496499 & 2.746615 & 3.013386 & 3.155228 & 3.566878 & 4.213839 & 4.775253 & $\mathrm{y}=0.4047 \mathrm{x}+1.0635$ & 0.9954 \\
\hline 3 & Guangzhou & Eastern & 1.670687 & 1.810041 & 1.954744 & 2.150315 & 2.676991 & 3.534283 & 4.42808 & 5.49531 & $y=0.1697 x+1.212$ & 0.999 \\
\hline 4 & Shenzhen & Eastern & 1.600182 & 1.750286 & 1.94926 & 2.249006 & 6.827965 & 8.959036 & 9.394507 & 9.633126 & $y=0.1792 x+0.3274$ & 0.6705 \\
\hline 5 & Tianjin & Eastern & 1.572693 & 1.653819 & 1.788539 & 1.854919 & 5.901592 & 6.248347 & 6.441155 & 6.67073 & $y=0.3837 x-0.706$ & 0.956 \\
\hline 6 & Chongqing & Central & 1.42622 & 1.571727 & 1.774059 & 1.942473 & 0.662438 & 0.81481 & 0.900102 & 1.039407 & $y=1.4165 x+0.4687$ & 0.9746 \\
\hline 7 & Hangzhou & Eastern & 0.920616 & 1.005021 & 1.131372 & 1.260336 & 2.782885 & 3.022515 & 3.985984 & 4.35391 & $\mathrm{y}=0.1934 \mathrm{x}+0.3956$ & 0.9616 \\
\hline 8 & Nanjing & Eastern & 0.882075 & 0.972077 & 1.050302 & 1.17151 & 2.497384 & 2.930633 & 3.550194 & 4.445725 & $\mathrm{y}=0.1445 \mathrm{x}+0.5339$ & 0.9909 \\
\hline 9 & Qingdao & Eastern & 0.86921 & 0.930007 & 1.001129 & 1.103728 & 1.760078 & 1.887759 & 2.111393 & 2.364463 & $\mathrm{y}=0.3787 x+0.2068$ & 0.9962 \\
\hline 10 & Dalian & Eastern & 0.765558 & 0.773164 & 0.68102 & 0.73639 & 1.75048 & 1.837818 & 1.917477 & 1.981108 & $y=-0.2446 x+1.1969$ & 0.3415 \\
\hline 11 & Ningbo & Eastern & 0.761028 & 0.800361 & 0.868649 & 0.98421 & 1.560726 & 1.969064 & 2.056487 & 2.125499 & $y=0.31 x+0.256$ & 0.6433 \\
\hline 12 & Xiamen & Eastern & 0.327358 & 0.346603 & 0.378427 & 0.43517 & 6.883743 & 7.503913 & 7.690256 & 7.821306 & $\mathrm{y}=0.0947 \mathrm{x}-0.3358$ & 0.6945 \\
\hline 13 & Ji'nan & Eastern & 0.57706 & 0.610023 & 0.653612 & 0.720196 & 1.30219 & 1.353739 & 1.427773 & 1.692866 & $\mathrm{y}=0.3468 \mathrm{x}+0.1394$ & 0.9479 \\
\hline 14 & Suzhou & Eastern & 1.376089 & 1.450407 & 1.54751 & 1.731951 & 3.440061 & 3.859497 & 4.561366 & 6.548412 & $\mathrm{y}=0.1107 x+1.0168$ & 0.9822 \\
\hline 15 & Wuhan & Central & 1.006948 & 1.09056 & 1.191261 & 1.341034 & 2.750418 & 2.951396 & 3.20614 & 3.695856 & $\mathrm{y}=0.3509 x+0.0517$ & 0.9939 \\
\hline 16 & Chengdu & Western & 1.005683 & 1.080116 & 1.217023 & 1.388939 & 3.358756 & 4.236498 & 4.594147 & 5.561516 & $\mathrm{y}=0.1801 x+0.3738$ & 0.9487 \\
\hline 17 & Changsha & Central & 0.782481 & 0.851013 & 0.945536 & 1.021013 & 1.533576 & 1.756367 & 2.052184 & 3.297249 & $\mathrm{y}=0.1215 \mathrm{x}+0.6375$ & 0.8346 \\
\hline 18 & Xi'an & Western & 0.549264 & 0.58012 & 0.625718 & 0.746985 & 3.196316 & 3.865494 & 4.135966 & 4.471107 & $\mathrm{y}=0.1421 \mathrm{x}+0.0688$ & 0.7828 \\
\hline 19 & Shenyang & Eastern & 0.709871 & 0.728 & 0.546001 & 0.586497 & 2.014167 & 2.150415 & 2.203039 & 2.292415 & $\mathrm{y}=-0.5466 \mathrm{x}+1.8259$ & 0.4997 \\
\hline 20 & Zhengzhou & Eastern & 0.667699 & 0.731152 & 0.802531 & 0.91302 & 1.740456 & 2.115113 & 2.676731 & 2.880727 & $\mathrm{y}=0.1937 \mathrm{x}+0.3227$ & 0.9216 \\
\hline 21 & Dongguan & Eastern & 0.588118 & 0.627506 & 0.682767 & 0.758209 & 1.030598 & 1.501366 & 2.197582 & 2.854381 & $\mathrm{y}=0.092 x+0.4898$ & 0.992 \\
\hline 22 & Fuzhou & Eastern & 0.516916 & 0.561808 & 0.619764 & 0.71034 & 0.902237 & 2.082021 & 2.257173 & 2.395907 & $\mathrm{y}=0.0982 \mathrm{x}+0.4147$ & 0.6464 \\
\hline 23 & Wuxi & Eastern & 0.820531 & 0.851826 & 0.921002 & 1.05118 & 2.153178 & 3.162821 & 3.301254 & 3.867276 & $\mathrm{y}=0.1253 \mathrm{x}+0.5199$ & 0.7635 \\
\hline 24 & Harbin & Eastern & 0.534007 & 0.575121 & 0.610161 & 0.635505 & 0.483118 & 0.51934 & 0.584794 & 0.615797 & $\mathrm{y}=0.7215 \mathrm{x}+0.1913$ & 0.9782 \\
\hline 25 & Foshan & Eastern & 0.760328 & 0.800392 & 0.863 & 0.95496 & 4.658889 & 5.297152 & 5.517081 & 5.916113 & $\mathrm{y}=0.1522 \mathrm{x}+0.0309$ & 0.8897 \\
\hline 26 & Changchun & Eastern & 0.534243 & 0.553003 & 0.591794 & 0.653003 & 0.937574 & 1.229054 & 1.432111 & 1.486014 & $\mathrm{y}=0.1836 \mathrm{x}+0.3497$ & 0.7557 \\
\hline 27 & Shijiazhuang & Eastern & 0.517027 & 0.54406 & 0.592773 & 0.646088 & 2.650926 & 2.756092 & 2.828802 & 2.846626 & $\mathrm{y}=0.5834 x-1.0413$ & 0.8326 \\
\hline 28 & Taiyuan & Central & 0.253109 & 0.273534 & 0.29556 & 0.338218 & 0.925942 & 0.96981 & 1.230886 & 1.398845 & $\mathrm{y}=0.1582 \mathrm{x}+0.1111$ & 0.9397 \\
\hline 29 & Yantai & Eastern & 0.600208 & 0.644608 & 0.69257 & 0.733895 & 0.571782 & 0.624688 & 0.692235 & 0.923017 & $\mathrm{y}=0.3473 \mathrm{x}+0.4237$ & 0.8592 \\
\hline 30 & Hefei & Central & 0.515797 & 0.566027 & 0.627438 & 0.721345 & 1.07847 & 1.916291 & 2.42456 & 2.662393 & $y=0.1166 x+0.372$ & 0.8532 \\
\hline 31 & Kunming & Western & 0.371299 & 0.396801 & 0.430008 & 0.485764 & 0.764001 & 0.918156 & 1.01496 & 1.177625 & $\mathrm{y}=0.2808 \mathrm{x}+0.1489$ & 0.9709 \\
\hline 32 & Wenzhou & Eastern & 0.430281 & 0.461984 & 0.50454 & 0.545317 & 0.987931 & 1.447027 & 1.584584 & 2.000244 & $\mathrm{y}=0.1169 x+0.3096$ & 0.9462 \\
\hline
\end{tabular}


Table A1. Cont.

\begin{tabular}{|c|c|c|c|c|c|c|c|c|c|c|c|c|}
\hline \multirow{2}{*}{ No. } & \multirow{2}{*}{ Cities } & \multirow[b]{2}{*}{ Location of the Cities } & \multicolumn{4}{|c|}{ Municipal GDP (trillion CNY) } & \multicolumn{4}{|c|}{ OSM RND Represent the OSM Road Network Density } & \multirow{2}{*}{ Regression Equation } & \multirow{2}{*}{ Coefficient of Determination $\left(R^{2}\right.$} \\
\hline & & & 2014 & 2015 & 2016 & 2017 & 2014 & 2015 & 2016 & 2017 & & \\
\hline 33 & Nanning & Western & 0.31483 & 0.341009 & 0.370339 & 0.411883 & 0.304956 & 0.405285 & 0.406003 & 0.589919 & $y=0.3344 x+0.2169$ & 0.9107 \\
\hline 34 & Nanchang & Central & 0.366796 & 0.400001 & 0.435499 & 0.500319 & 4.445648 & 5.080118 & 5.207499 & 5.528507 & $y=0.1164 x-0.1642$ & 0.8569 \\
\hline 35 & Tangshan & Eastern & 0.62253 & 0.61 & 0.63062 & 0.71061 & 0.692859 & 0.858997 & 0.905533 & 1.472886 & $y=0.1277 x+0.518$ & 0.9037 \\
\hline 36 & Zibo & Eastern & 0.402977 & 0.41302 & 0.441201 & 0.478132 & 0.953503 & 0.988958 & 1.8103 & 2.013233 & $y=0.058 x+0.3503$ & 0.8951 \\
\hline 37 & Changzhou & Eastern & 0.490187 & 0.52732 & 0.577386 & 0.662228 & 1.340996 & 1.801608 & 1.848598 & 3.019328 & $y=0.1003 x+0.3634$ & 0.9294 \\
\hline 38 & Quanzhou & Eastern & 0.573336 & 0.613774 & 0.664663 & 0.754801 & 0.634438 & 0.920326 & 1.384851 & 1.342822 & $\mathrm{y}=0.1867 \mathrm{x}+0.4517$ & 0.7318 \\
\hline 39 & Guiyang & Eastern & 0.249727 & 0.289116 & 0.31577 & 0.353796 & 1.4045 & 1.561081 & 1.73026 & 2.215922 & $\mathrm{y}=0.1197 \mathrm{x}+0.0952$ & 0.9203 \\
\hline 40 & Jiaxing & Eastern & 0.33528 & 0.351706 & 0.37601 & 0.435524 & 1.127291 & 1.266025 & 1.598774 & 1.725241 & $\mathrm{y}=0.1447 \mathrm{x}+0.1678$ & 0.8476 \\
\hline 41 & Nantong & Eastern & 0.565279 & 0.61484 & 0.67682 & 0.77346 & 0.587234 & 1.243394 & 2.189651 & 2.424369 & $\mathrm{y}=0.0989 x+0.4982$ & 0.8832 \\
\hline 42 & $\begin{array}{l}\text { Jinhua } \\
\end{array}$ & Eastern & 0.320664 & 0.34065 & 0.363501 & 0.387022 & 0.314445 & 0.663407 & 0.705874 & 0.910499 & $y=0.1096 x+0.2819$ & 0.8947 \\
\hline 43 & Zhuhai & Eastern & 0.185732 & 0.202498 & 0.222637 & 0.256473 & 2.257383 & 2.892806 & 3.178339 & 3.573405 & $y=0.0525 x+0.0605$ & 0.9154 \\
\hline 44 & Huizhou & Eastern & 0.30007 & 0.314003 & 0.341217 & 0.383058 & 0.54594 & 0.681892 & 0.733018 & 0.937024 & $\mathrm{y}=0.2204 \mathrm{x}+0.1749$ & 0.9566 \\
\hline 45 & Xuzhou & Eastern & 0.496391 & 0.531988 & 0.580852 & 0.660595 & 0.839667 & 0.833549 & 1.604102 & 3.131913 & $\mathrm{y}=0.0638 \mathrm{x}+0.4653$ & 0.9418 \\
\hline 46 & Haikou & Eastern & 0.10917 & 0.116196 & 0.125767 & 0.139058 & 1.215575 & 1.39047 & 1.391586 & 1.593147 & $y=0.0796 x+0.0113$ & 0.9019 \\
\hline 47 & Urumqi & Western & 0.246147 & 0.263164 & 0.245898 & 0.274382 & 1.471562 & 1.488615 & 1.548517 & 1.676137 & $\mathrm{y}=0.1043 \mathrm{x}+0.0962$ & 0.4828 \\
\hline 48 & Shaoxing & Eastern & 0.426583 & 0.446665 & 0.471 & 0.510804 & 0.758167 & 0.803163 & 1.000226 & 1.245672 & $\mathrm{y}=0.1613 \mathrm{x}+0.3103$ & 0.9789 \\
\hline 49 & Zhongshan & Eastern & 0.28233 & 0.301003 & 0.320278 & 0.345031 & 1.636848 & 1.759837 & 2.144733 & 2.393204 & $y=0.0758 x+0.1617$ & 0.9693 \\
\hline 51 & Lanzhou & Western & 0.200094 & 0.209599 & 0.226423 & 0.252354 & 0.623852 & 0.644902 & 0.723011 & 1.678987 & $\mathrm{y}=0.0412 \mathrm{x}+0.1843$ & 0.8392 \\
\hline 52 & Weifang & Eastern & 0.478674 & 0.517053 & 0.55227 & 0.585863 & 0.808287 & 1.067039 & 1.251496 & 2.839208 & $y=0.0438 x+0.4681$ & 0.7604 \\
\hline 53 & Baoding & Eastern & 0.30352 & 0.300034 & 0.32273 & 0.35809 & 1.08439 & 1.307091 & 1.321359 & 1.482171 & $y=0.1299 x+0.1524$ & 0.637 \\
\hline 54 & Zhenjiang & Eastern & 0.325238 & 0.350248 & 0.383384 & 0.401036 & 0.877717 & 1.211188 & 1.385888 & 1.712882 & $\mathrm{y}=0.0949 x+0.2419$ & 0.955 \\
\hline 55 & Yangzhou & Eastern & 0.369789 & 0.401684 & 0.444938 & 0.506492 & 1.440231 & 1.801123 & 2.298118 & 2.526604 & $\mathrm{y}=0.117 \mathrm{x}+0.1947$ & 0.9365 \\
\hline 56 & Hohhot & Western & 0.289405 & 0.309052 & 0.317359 & 0.274372 & 0.567368 & 0.655892 & 0.859838 & 0.869946 & $\mathrm{y}=-0.0029 \mathrm{x}+0.2997$ & 0.0005 \\
\hline 57 & Langfang & Eastern & 0.217596 & 0.24019 & 0.27063 & 0.28806 & 0.437621 & 0.726791 & 0.791253 & 1.032201 & $y=0.1226 x+0.1626$ & 0.9129 \\
\hline 58 & Luoyang & Central & 0.328457 & 0.350875 & 0.37829 & 0.429019 & 0.908334 & 1.110387 & 1.912928 & 2.084188 & $\mathrm{y}=0.069 \mathrm{x}+0.2679$ & 0.856 \\
\hline 59 & Weihai & Eastern & 0.279034 & 0.300157 & 0.32122 & 0.34801 & 1.158146 & 1.249603 & 1.297057 & 1.523613 & $y=0.1835 x+0.0723$ & 0.935 \\
\hline 60 & Yancheng & Eastern & 0.383562 & 0.42125 & 0.457608 & 0.508269 & 0.657349 & 0.692985 & 0.894144 & 1.233145 & $y=0.194 x+0.274$ & 0.9275 \\
\hline 61 & Linyi & Eastern & 0.35698 & 0.37632 & 0.402675 & 0.434539 & 1.480754 & 2.084111 & 2.317847 & 2.54728 & $y=0.0686 x+0.2481$ & 0.8741 \\
\hline 62 & Jiangmen & Eastern & 0.208276 & 0.224002 & 0.241878 & 0.269025 & 1.3465 & 1.558839 & 1.660016 & 1.74101 & $\mathrm{y}=0.1434 \mathrm{x}+0.0097$ & 0.8806 \\
\hline 63 & $\begin{array}{c}\text { Taizhou } \\
\text { (Jiangsu) }\end{array}$ & Eastern & 0.337089 & 0.365553 & 0.410178 & 0.474453 & 0.822494 & 1.257907 & 1.596425 & 2.136174 & $y=0.107 x+0.2414$ & 0.9821 \\
\hline 64 & Zhangzhou & Eastern & 0.250636 & 0.276745 & 0.312534 & 0.352853 & 0.916913 & 1.151741 & 1.200081 & 1.38604 & $y=0.2206 x+0.0414$ & 0.9201 \\
\hline 65 & Handan & Eastern & 0.308001 & 0.31454 & 0.33371 & 0.36663 & 0.675282 & 0.813087 & 0.914555 & 0.949443 & $y=0.1836 x+0.1769$ & 0.7366 \\
\hline
\end{tabular}


Table A1. Cont.

\begin{tabular}{|c|c|c|c|c|c|c|c|c|c|c|c|c|}
\hline \multirow{2}{*}{ No. } & \multirow{2}{*}{ Cities } & \multirow[b]{2}{*}{ Location of the Cities } & \multicolumn{4}{|c|}{ Municipal GDP (trillion CNY) } & \multicolumn{4}{|c|}{ OSM RND Represent the OSM Road Network Density } & \multirow{2}{*}{ Regression Equation } & \multirow{2}{*}{ Coefficient of Determination $\left(R^{2}\right)$} \\
\hline & & & 2014 & 2015 & 2016 & 2017 & 2014 & 2015 & 2016 & 2017 & & \\
\hline 66 & Jining & Western & 0.380006 & 0.401312 & 0.430182 & 0.465057 & 0.471934 & 0.526896 & 0.776055 & 0.91366 & $y=0.1739 x+0.3022$ & 0.966 \\
\hline 67 & Wuhu & Eastern & 0.23079 & 0.245732 & 0.269944 & 0.306552 & 0.672768 & 0.965252 & 1.227687 & 1.957186 & $\mathrm{y}=0.0598 \mathrm{x}+0.1912$ & 0.9873 \\
\hline 68 & Yinchuan & Central & 0.139567 & 0.148073 & 0.161728 & 0.180317 & 0.497675 & 0.59603 & 0.693312 & 0.716513 & $y=0.164 x+0.0548$ & 0.8525 \\
\hline 69 & Liuzhou & Eastern & 0.220851 & 0.229862 & 0.247694 & 0.275564 & 0.455206 & 0.485649 & 0.604588 & 0.599445 & $\mathrm{y}=0.2719 \mathrm{x}+0.0977$ & 0.7542 \\
\hline 70 & Mianyang & Western & 0.157989 & 0.170033 & 0.183042 & 0.207475 & 0.445944 & 0.554054 & 0.707322 & 0.734055 & $\mathrm{y}=0.1434 \mathrm{x}+0.0921$ & 0.838 \\
\hline 71 & Zhanjiang & Eastern & 0.22587 & 0.238002 & 0.258478 & 0.282403 & 1.405769 & 1.659609 & 2.261492 & 2.575143 & $\mathrm{y}=0.0455 \mathrm{x}+0.1613$ & 0.9729 \\
\hline 72 & Anshan & Eastern & 0.2349 & 0.2326 & 0.14408 & 0.16021 & 0.727266 & 0.768087 & 0.816542 & 0.828872 & $\mathrm{y}=-0.9284 \mathrm{x}+0.9219$ & 0.8297 \\
\hline 73 & Daqing & Eastern & 0.407 & 0.29835 & 0.261 & 0.26805 & 0.499983 & 1.191177 & 1.2228 & 1.222723 & $\mathrm{y}=-0.1858 x+0.5007$ & 0.9601 \\
\hline 74 & Yichang & Central & 0.313221 & 0.33848 & 0.370936 & 0.385717 & 1.996736 & 2.126815 & 2.172778 & 2.900025 & $\mathrm{y}=0.0641 \mathrm{x}+0.2048$ & 0.6429 \\
\hline 75 & Baotou & Eastern & 0.363631 & 0.378193 & 0.386763 & 0.275303 & 0.601152 & 0.628997 & 0.851639 & 0.900335 & $\mathrm{y}=-0.1854 \mathrm{x}+0.4892$ & 0.3029 \\
\hline 76 & Jilin & Eastern & 0.27302 & 0.24552 & 0.253135 & 0.23028 & 0.601762 & 0.695863 & 0.781348 & 0.880384 & $\mathrm{y}=-0.1324 x+0.3484$ & 0.7854 \\
\hline 77 & Huai'an & Eastern & 0.245539 & 0.274509 & 0.3048 & 0.338743 & 0.549558 & 0.656979 & 0.695744 & 0.776926 & $\mathrm{y}=0.4165 \mathrm{x}+0.0119$ & 0.9658 \\
\hline 78 & Cangzhou & Eastern & 0.313338 & 0.32406 & 0.35334 & 0.38169 & 0.746255 & 0.809976 & 0.888409 & 1.36473 & $\mathrm{y}=0.1017 \mathrm{x}+0.2462$ & 0.8629 \\
\hline 79 & Xiangyang & Central & 0.31293 & 0.338212 & 0.369451 & 0.40649 & 0.347927 & 0.424744 & 0.563634 & 0.594033 & $\mathrm{y}=0.3347 \mathrm{x}+0.1952$ & 0.9255 \\
\hline 80 & Yueyang & Central & 0.266939 & 0.288628 & 0.310087 & 0.325803 & 0.78718 & 0.829211 & 0.870221 & 1.291411 & $\mathrm{y}=0.0898 x+0.2131$ & 0.67 \\
\hline 81 & Taian & Eastern & 0.300219 & 0.31584 & 0.33168 & 0.358528 & 0.935667 & 1.041736 & 1.769295 & 1.918874 & $y=0.0462 x+0.2612$ & 0.8588 \\
\hline 82 & Dongying & Eastern & 0.343049 & 0.345064 & 0.34796 & 0.380178 & 0.455815 & 0.496966 & 0.737227 & 0.774951 & $\mathrm{y}=0.0783 \mathrm{x}+0.3058$ & 0.5307 \\
\hline 85 & Lhasa & Western & 0.034745 & 0.038946 & 0.042495 & 0.047916 & 0.497234 & 0.788384 & 0.857679 & 0.901169 & $\mathrm{y}=0.0273 x+0.0203$ & 0.7902 \\
\hline
\end{tabular}

Table A2. The statistical results for predictive GDP of 85 Chinese cities in 2018.

\begin{tabular}{|c|c|c|c|c|c|c|c|c|c|}
\hline No. & Cities & $\begin{array}{l}\text { Location of } \\
\text { the Cities }\end{array}$ & $\begin{array}{l}\text { GDP in } 2018 \\
\text { (trillion CNY) }\end{array}$ & $\begin{array}{c}\text { Predictive GDP in } \\
2018 \text { by Using OSM } \\
\text { Road Network } \\
\text { Density (trillion CNY) }\end{array}$ & $\begin{array}{l}\text { Predictive GDP in } 2018 \text { by } \\
\text { Using OSM Road } \\
\text { Network Density and } \\
\text { Population (trillion CNY) }\end{array}$ & $\begin{array}{l}\text { Absolute Residuals by } \\
\text { Using OSM Road } \\
\text { Network Density }\end{array}$ & $\begin{array}{l}\text { Relative Residuals by } \\
\text { Using OSM Road } \\
\text { Network Density }\end{array}$ & $\begin{array}{c}\text { Absolute Residuals by } \\
\text { Using OSM Road } \\
\text { Network Density and } \\
\text { Population }\end{array}$ & $\begin{array}{c}\text { Relative Residuals by } \\
\text { Using OSM Road } \\
\text { Network Density and } \\
\text { Population }\end{array}$ \\
\hline 1 & Beijing & Eastern & 3.0320 & 3.1938 & 3.4422 & 0.1618 & 5.3364 & 0.4102 & 13.5290 \\
\hline 2 & Shanghai & Eastern & 3.2680 & 3.0637 & 3.0811 & -0.2043 & -6.2515 & -0.1869 & -5.7191 \\
\hline 3 & Guangzhou & Eastern & 2.2859 & 2.2386 & 2.2264 & -0.0473 & -2.0692 & -0.0595 & -2.6029 \\
\hline 4 & Shenzhen & Eastern & 2.4222 & 2.1405 & 2.4473 & -0.2817 & -11.6299 & 0.0251 & 1.0362 \\
\hline 5 & Tianjin & Eastern & 1.8810 & 2.1958 & 2.2128 & 0.3149 & 16.7358 & 0.3318 & 17.6396 \\
\hline 6 & Chongqing & Central & 2.0363 & 2.4803 & 2.0682 & 0.4440 & 21.8043 & 0.0319 & 1.5666 \\
\hline 7 & Hangzhou & Eastern & 1.3509 & 1.5446 & 1.5063 & 0.1937 & 14.3386 & 0.1554 & 11.5034 \\
\hline
\end{tabular}


Table A2. Cont.

\begin{tabular}{|c|c|c|c|c|c|c|c|c|c|}
\hline No. & Cities & $\begin{array}{l}\text { Location of } \\
\text { the Cities }\end{array}$ & $\begin{array}{c}\text { GDP in } 2018 \\
\text { (trillion CNY) }\end{array}$ & $\begin{array}{c}\text { Predictive GDP in } \\
2018 \text { by Using OSM } \\
\text { Road Network } \\
\text { Density (trillion CNY) }\end{array}$ & $\begin{array}{l}\text { Predictive GDP in } 2018 \text { by } \\
\text { Using OSM Road } \\
\text { Network Density and } \\
\text { Population (trillion CNY) }\end{array}$ & $\begin{array}{l}\text { Absolute Residuals by } \\
\text { Using OSM Road } \\
\text { Network Density }\end{array}$ & $\begin{array}{l}\text { Relative Residuals by } \\
\text { Using OSM Road } \\
\text { Network Density }\end{array}$ & $\begin{array}{c}\text { Absolute Residuals by } \\
\text { Using OSM Road } \\
\text { Network Density and } \\
\text { Population }\end{array}$ & $\begin{array}{c}\text { Relative Residuals by } \\
\text { Using OSM Road } \\
\text { Network Density anc } \\
\text { Population }\end{array}$ \\
\hline 8 & Nanjing & Eastern & 1.2820 & 1.2024 & 1.0471 & -0.0797 & -6.2090 & -0.2349 & -18.3229 \\
\hline 9 & Qingdao & Eastern & 1.2002 & 1.2330 & 1.2537 & 0.0328 & 2.7329 & 0.0535 & 4.4576 \\
\hline 10 & Dalian & Eastern & 0.7669 & 0.5997 & 0.7002 & -0.1672 & -21.8021 & -0.0667 & -8.6974 \\
\hline 11 & Ningbo & Eastern & 1.0746 & 0.9531 & 1.1785 & -0.1215 & -11.3065 & 0.1039 & 9.6687 \\
\hline 12 & Xiamen & Eastern & 0.4791 & 0.4474 & 0.4887 & -0.0317 & -6.6166 & 0.0096 & 2.0038 \\
\hline 13 & Ji'nan & Eastern & 0.7857 & 1.0287 & 0.8826 & 0.2430 & 30.9278 & 0.0969 & 12.3330 \\
\hline 14 & Suzhou & Eastern & 1.8565 & 1.9590 & 1.9216 & 0.1025 & 5.5211 & 0.0651 & 3.5066 \\
\hline 15 & Wuhan & Central & 1.4847 & 1.4228 & 1.4250 & -0.0619 & -4.1692 & -0.0597 & -4.0210 \\
\hline 16 & Chengdu & Western & 1.5254 & 1.5929 & 1.5392 & 0.0675 & 4.4251 & 0.0138 & 0.9047 \\
\hline 17 & Changsha & Central & 1.1003 & 1.0682 & 1.2354 & -0.0322 & -2.9174 & 0.1351 & 12.2785 \\
\hline 18 & Xi'an & Western & 0.8350 & 0.7505 & 1.2377 & -0.0845 & -10.1198 & 0.4027 & 48.2275 \\
\hline 19 & Shenyang & Eastern & 0.6292 & 0.4871 & 2.5457 & -0.1421 & -22.5842 & 1.9165 & 304.5931 \\
\hline 20 & Zhengzhou & Eastern & 1.0143 & 1.0272 & 1.0107 & 0.0128 & 1.2718 & -0.0036 & -0.3549 \\
\hline 21 & Dongguan & Eastern & 0.8279 & 0.8223 & 0.8294 & -0.0056 & -0.6764 & 0.0015 & 0.1812 \\
\hline 22 & Fuzhou & Eastern & 0.7857 & 0.6961 & 0.7764 & -0.0895 & -11.4038 & -0.0093 & -1.1837 \\
\hline 23 & Wuxi & Eastern & 1.1439 & 1.0292 & 1.1492 & -0.1146 & -10.0271 & 0.0053 & 0.4633 \\
\hline 24 & Harbin & Eastern & 0.6301 & 0.6759 & 0.6757 & 0.0458 & 7.2687 & 0.0456 & 7.2369 \\
\hline 25 & Foshan & Eastern & 0.9936 & 1.1602 & 1.1390 & 0.1666 & 16.7673 & 0.1454 & 14.6337 \\
\hline 26 & Changchun & Eastern & 0.7176 & 0.6533 & 0.6331 & -0.0643 & -8.9604 & -0.0845 & -11.7754 \\
\hline 27 & Shijiazhuang & Eastern & 0.6083 & 0.8995 & 0.5967 & 0.2913 & 47.8711 & -0.0116 & -1.9070 \\
\hline 28 & Taiyuan & Central & 0.3884 & 0.3584 & 0.3837 & -0.0301 & -7.7240 & -0.0047 & -1.2101 \\
\hline 29 & Yantai & Eastern & 0.7833 & 0.7658 & 0.7777 & -0.0174 & -2.2341 & -0.0056 & -0.7149 \\
\hline 30 & Hefei & Central & 0.7823 & 0.7452 & 0.8277 & -0.0371 & -4.7424 & 0.0454 & 5.8034 \\
\hline 31 & Kunming & Western & 0.5207 & 0.5186 & 0.4968 & -0.0021 & -0.4033 & -0.0239 & -4.5900 \\
\hline 32 & Wenzhou & Eastern & 0.6006 & 0.5519 & 0.5490 & -0.0487 & -8.1086 & -0.0516 & -8.5914 \\
\hline 33 & Nanning & Western & 0.4147 & 0.4548 & 0.4532 & 0.0401 & 9.6696 & 0.0385 & 9.2838 \\
\hline 34 & Nanchang & Central & 0.5275 & 0.5144 & 0.5443 & -0.0131 & -2.4834 & 0.0168 & 3.1848 \\
\hline 35 & Tangshan & Eastern & 0.6955 & 0.7423 & 0.7444 & 0.0468 & 6.7290 & 0.0489 & 7.0309 \\
\hline 36 & Zibo & Eastern & 0.5068 & 0.4839 & 0.4693 & -0.0230 & -4.5185 & -0.0375 & -7.3994 \\
\hline 37 & Changzhou & Eastern & 0.7050 & 0.6780 & 0.7372 & -0.0270 & -3.8298 & 0.0322 & 4.5674 \\
\hline 38 & Quanzhou & Eastern & 0.8468 & 0.7687 & 0.7780 & -0.0781 & -9.2230 & -0.0688 & -8.1247 \\
\hline
\end{tabular}


Table A2. Cont.

\begin{tabular}{|c|c|c|c|c|c|c|c|c|c|}
\hline No. & Cities & $\begin{array}{l}\text { Location of } \\
\text { the Cities }\end{array}$ & $\begin{array}{c}\text { GDP in } 2018 \\
\text { (trillion CNY) }\end{array}$ & $\begin{array}{c}\text { Predictive GDP in } \\
2018 \text { by Using OSM } \\
\text { Road Network } \\
\text { Density (trillion CNY) }\end{array}$ & $\begin{array}{l}\text { Predictive GDP in } 2018 \text { by } \\
\text { Using OSM Road } \\
\text { Network Density and } \\
\text { Population (trillion CNY) }\end{array}$ & $\begin{array}{l}\text { Absolute Residuals by } \\
\text { Using OSM Road } \\
\text { Network Density }\end{array}$ & $\begin{array}{l}\text { Relative Residuals by } \\
\text { Using OSM Road } \\
\text { Network Density }\end{array}$ & $\begin{array}{c}\text { Absolute Residuals by } \\
\text { Using OSM Road } \\
\text { Network Density and } \\
\text { Population }\end{array}$ & $\begin{array}{c}\text { Relative Residuals by } \\
\text { Using OSM Road } \\
\text { Network Density anc } \\
\text { Population }\end{array}$ \\
\hline 39 & Guiyang & Eastern & 0.3798 & 0.4347 & 0.3671 & 0.0549 & 14.4550 & -0.0127 & -3.3439 \\
\hline 40 & Jiaxing & Eastern & 0.4872 & 0.4513 & 0.4875 & -0.0359 & -7.3686 & 0.0003 & 0.0616 \\
\hline 41 & Nantong & Eastern & 0.8427 & 0.7887 & 0.9330 & -0.0540 & -6.4080 & 0.0903 & 10.7156 \\
\hline 42 & Jinhua & Eastern & 0.4100 & 0.3952 & 0.4049 & -0.0148 & -3.6098 & -0.0051 & -1.2439 \\
\hline 43 & Zhuhai & Eastern & 0.2915 & 0.2626 & 0.3010 & -0.0288 & -9.9142 & 0.0095 & 3.2590 \\
\hline 44 & Huizhou & Eastern & 0.4103 & 0.3910 & 0.3898 & -0.0193 & -4.7039 & -0.0205 & -4.9963 \\
\hline 45 & Xuzhou & Eastern & 0.6755 & 0.6919 & 0.7017 & 0.0164 & 2.4278 & 0.0262 & 3.8786 \\
\hline 46 & Haikou & Eastern & 0.1511 & 0.2083 & 0.1459 & 0.0573 & 37.8557 & -0.0052 & -3.4414 \\
\hline 47 & Urumqi & Western & 0.3100 & 0.2892 & 0.3181 & -0.0207 & -6.7097 & 0.0081 & 2.6129 \\
\hline 48 & Shaoxing & Eastern & 0.5417 & 0.5172 & 0.5427 & -0.0244 & -4.5228 & 0.001 & 0.1846 \\
\hline 49 & Zhongshan & Eastern & 0.3633 & 0.3738 & 0.4142 & 0.0105 & 2.8902 & 0.0509 & 14.0105 \\
\hline 50 & $\begin{array}{c}\text { Taizhou } \\
\text { (Zhejiang) }\end{array}$ & Eastern & 0.4875 & 0.4979 & 0.4914 & 0.0105 & 2.1333 & 0.0039 & 0.8000 \\
\hline 51 & Lanzhou & Western & 0.2733 & 0.2572 & 0.2673 & -0.0161 & -5.8910 & -0.006 & -2.1954 \\
\hline 52 & Weifang & Eastern & 0.6157 & 0.6289 & 0.6077 & 0.0132 & 2.1439 & -0.008 & -1.2993 \\
\hline 53 & Baoding & Eastern & 0.3590 & 0.4259 & 0.4253 & 0.0669 & 18.6351 & 0.0663 & 18.4680 \\
\hline 54 & Zhenjiang & Eastern & 0.4050 & 0.4095 & 0.5013 & 0.0045 & 1.1111 & 0.0963 & 23.7778 \\
\hline 55 & Yangzhou & Eastern & 0.5466 & 0.5026 & 0.5821 & -0.0440 & -8.0498 & 0.0355 & 6.4947 \\
\hline 56 & Hohhot & Western & 0.2904 & 0.2969 & 0.2957 & 0.0066 & 2.2383 & 0.0053 & 1.8251 \\
\hline 57 & Langfang & Eastern & 0.3108 & 0.3112 & 0.3174 & 0.0004 & 0.1287 & 0.0066 & 2.1236 \\
\hline 58 & Luoyang & Central & 0.4641 & 0.4307 & 0.4405 & -0.0334 & -7.1967 & -0.0236 & -5.0851 \\
\hline 59 & Weihai & Eastern & 0.3641 & 0.3568 & 0.3589 & -0.0073 & -2.0049 & -0.0052 & -1.4282 \\
\hline 60 & Yancheng & Eastern & 0.5487 & 0.5544 & 0.3228 & 0.0057 & 1.0388 & -0.2259 & -41.1700 \\
\hline 61 & Linyi & Eastern & 0.4718 & 0.4571 & 0.4416 & -0.0147 & -3.1157 & -0.0302 & -6.4010 \\
\hline 62 & Jiangmen & Eastern & 0.2900 & 0.2910 & 0.3001 & 0.0010 & 0.3448 & 0.0101 & 3.4828 \\
\hline 63 & $\begin{array}{c}\text { Taizhou } \\
\text { (Jiangsu) }\end{array}$ & Eastern & 0.5108 & 0.4790 & 0.2763 & -0.0317 & -6.2255 & -0.2345 & -45.9084 \\
\hline 64 & Zhangzhou & Eastern & 0.3948 & 0.4722 & 0.4006 & 0.0774 & 19.6049 & 0.0058 & 1.4691 \\
\hline 65 & Handan & Eastern & 0.3455 & 0.3577 & 0.3600 & 0.0122 & 3.5311 & 0.0145 & 4.1968 \\
\hline 66 & Jining & Western & 0.4931 & 0.4905 & 0.4776 & -0.0026 & -0.5273 & -0.0155 & -3.1434 \\
\hline 67 & Wuhu & Eastern & 0.3279 & 0.3260 & 0.3294 & -0.0019 & -0.5794 & 0.0015 & 0.4575 \\
\hline 68 & Yinchuan & Central & 0.1901 & 0.2211 & 0.1720 & 0.0309 & 16.3072 & -0.0181 & -9.5213 \\
\hline
\end{tabular}


Table A2. Cont.

\begin{tabular}{|c|c|c|c|c|c|c|c|c|c|}
\hline No. & Cities & $\begin{array}{l}\text { Location of } \\
\text { the Cities }\end{array}$ & $\begin{array}{l}\text { GDP in } 2018 \\
\text { (trillion CNY) }\end{array}$ & $\begin{array}{c}\text { Predictive GDP in } \\
2018 \text { by Using OSM } \\
\text { Road Network } \\
\text { Density (trillion CNY) }\end{array}$ & $\begin{array}{l}\text { Predictive GDP in } 2018 \text { by } \\
\text { Using OSM Road } \\
\text { Network Density and } \\
\text { Population (trillion CNY) }\end{array}$ & $\begin{array}{l}\text { Absolute Residuals by } \\
\text { Using OSM Road } \\
\text { Network Density }\end{array}$ & $\begin{array}{l}\text { Relative Residuals by } \\
\text { Using OSM Road } \\
\text { Network Density }\end{array}$ & $\begin{array}{c}\text { Absolute Residuals by } \\
\text { Using OSM Road } \\
\text { Network Density and } \\
\text { Population }\end{array}$ & $\begin{array}{c}\text { Relative Residuals by } \\
\text { Using OSM Road } \\
\text { Network Density and } \\
\text { Population } \\
\end{array}$ \\
\hline 69 & Liuzhou & Eastern & 0.3084 & 0.3025 & 0.2880 & -0.0059 & -1.9131 & -0.0204 & -6.6148 \\
\hline 70 & Mianyang & Western & 0.2304 & 0.2376 & 0.1645 & 0.0072 & 3.1250 & -0.0659 & -28.6024 \\
\hline 71 & Zhanjiang & Eastern & 0.3008 & 0.2947 & 0.2966 & -0.0061 & -2.0279 & -0.0042 & -1.3963 \\
\hline 72 & Anshan & Eastern & 0.1751 & 0.1145 & 0.1012 & -0.0606 & -34.6088 & -0.0739 & -42.2045 \\
\hline 73 & Daqing & Eastern & 0.2801 & 0.2620 & 0.2582 & -0.0181 & -6.4620 & -0.0219 & -7.8186 \\
\hline 74 & Yichang & Central & 0.4064 & 0.4784 & 0.3904 & 0.0720 & 17.7165 & -0.016 & -3.9370 \\
\hline 75 & Baotou & Eastern & 0.2952 & 0.2298 & 0.3095 & -0.0654 & -22.1545 & 0.0143 & 4.8442 \\
\hline 76 & Jilin & Eastern & 0.2210 & 0.2180 & 0.2167 & -0.0030 & -1.3575 & -0.0043 & -1.9457 \\
\hline 77 & Huai'an & Eastern & 0.3601 & 0.4267 & 0.3499 & 0.0666 & 18.4949 & -0.0102 & -2.8325 \\
\hline 78 & Cangzhou & Eastern & 0.3676 & 0.4266 & 0.4065 & 0.0590 & 16.0501 & 0.0389 & 10.5822 \\
\hline 79 & Xiangyang & Central & 0.4310 & 0.4096 & 0.4381 & -0.0214 & -4.9652 & 0.0071 & 1.6473 \\
\hline 80 & Yueyang & Central & 0.3411 & 0.4007 & 0.3001 & 0.0596 & 17.4729 & -0.041 & -12.0199 \\
\hline 81 & Taian & Eastern & 0.3652 & 0.3579 & 0.3465 & -0.0072 & -1.9989 & -0.0187 & -5.1205 \\
\hline 82 & Dongying & Eastern & 0.4152 & 0.4105 & 0.3266 & -0.0047 & -1.1320 & -0.0886 & -21.3391 \\
\hline 83 & Nanyang & Central & 0.3567 & 0.3501 & 0.3379 & -0.0066 & -1.8503 & -0.0188 & -5.2705 \\
\hline 84 & Xining & Western & 0.1286 & 0.1322 & 0.1360 & 0.0035 & 2.7994 & 0.0074 & 5.7543 \\
\hline 85 & Lhasa & Western & 0.0528 & 0.0486 & 0.0515 & -0.0042 & -7.9545 & -0.0013 & -2.4621 \\
\hline
\end{tabular}




\section{References}

1. Gustafson, E.J. Quantifying landscape spatial pattern: What is the state of the art? Ecosystems 1998, 1, 143-156. [CrossRef]

2. Hargis, C.D.; Bissonette, J.A.; David, J.L. The behavior of landscape metrics commonly used in the study of habitat fragmentation. Landsc. Ecol. 1998, 13, 167-186. [CrossRef]

3. O'Neill, R.V.; Krummel, J.R.; Gardner, R.H.; Sugihara, G.; Jackson, B.; DeAngelis, D.L.; Milne, B.T.; Turner, M.G.; Zygmunt, B.; Christensen, S.W.; et al. Indices of landscape pattern. Landsc. Ecol. 1988, 1, 153-162. [CrossRef]

4. McGarigal, K.; Cushman, S.A.; Neel, M.C.; Ene, E. FRAGSTATS: Spatial Pattern Analysis Program for Categorical Maps. 2002. Available online: www.umass.edu/landeco/research/fragstats/fragstats.html (accessed on 15 May 2020).

5. Herold, M.; Liu, X.H.; Clarke, K.C. Spatial Metrics and Image Texture for Mapping Urban Land use. Photogramm. Eng. Remote Sens. 2003, 69, 991-1001. [CrossRef]

6. Herold, M.; Couclelis, H.; Clarke, K.C. The role of spatial metrics in the analysis and modeling of urban land use change. Comput. Environ. Urban Syst. 2005, 29, 369-399. [CrossRef]

7. Reis, J.P.; Silva, E.A.; Pinbo, P. Measure space: A review of spatial metrics for urban growth and shrinkage. In The Routledge Handbook of Planning Research Methods; Silva, E.A., Healey, P., Harris, N., Van den Broeck, P., Eds.; Routledge: New York, NY, USA, 2014; pp. 279-292.

8. Reis, J.P.; Silva, E.A.; Pinbo, P. Spatial metrics to study urban patterns in growing and shrinking cities. Urban Geogr. 2016, 37, 246-271. [CrossRef]

9. Chen, M.; Huang, Y.; Tang, Z.; Lu, D.; Liu, H.; Ma, L. The provincial pattern of the relationship between urbanization and economic development in China. J. Geogr. Sci. 2014, 24, 33-45. [CrossRef]

10. Henderson, V. The Urbanization Process and Economic Growth: The So-What Question. J. Econ. Growth 2003, 8, 47-71. [CrossRef]

11. Njoh, A.J. Urbanization and development in sub-Saharan Africa. Cities 2003, 20, 167-174. [CrossRef]

12. Liu, Y.S.; Fang, F.; Li, Y.H. Key issues of land use in China and implications for policy making. Land Use Policy 2014, 40, 6-12. [CrossRef]

13. Xiang, W.N.; Stuber, R.M.B.; Meng, X.C. Meeting critical challengers and striving for urban sustainability in China. Landsc. Urban Plan. 2011, 100, 418-420. [CrossRef] [PubMed]

14. Li, Y.Z. Urbanization and economic growth in China: An empirical research based on VAR model. Int. J. Econ. Financ. 2017, 9, 210-219.

15. Cai, Z.Y.; Liu, Q.; Cao, S.X. Real estate supports rapid development of China's urbanization. Land Use Policy 2020, 95, 104582. [CrossRef]

16. National Bureau of Statistics (NBS). China Statistical Yearbook; China statistics Press: Beijing, China, 2018.

17. Heshmati, A.; Rashidghalam, M. Measurement and Analysis of Urban Infrastructure and Its Effects on Urbanization in China. J. Infrastruct. Syst. 2020, 26, 04019030. [CrossRef]

18. Yu, N.N.; de Roo, G.; de Jong, M.; Storm, S. Does the expansion of a motorway network lead to economic agglomeration Evidence from China. Transp. Policy 2016, 45, 218-227. [CrossRef]

19. Jiao, J.; Wang, J.; Jin, F.; Du, C. Understanding Relationship between Accessibility and Economic Growth: A Case Study from China (1990-2010). Chin. Geogr. Sci. 2016, 26, 803-816. [CrossRef]

20. Worku, I. Road Sector Development and Economic Growth in Ethiopia. Ethiop. J. Econ. 2010, 19, $101-146$.

21. Ivanova, E.; Masarova, J. Importance of road infrastructure in the economic development and competitiveness. Compet. Nations Global Econ. 2013, 18, 263-274. [CrossRef]

22. Beyzatlar, M.A.; Karacal, M.; Yetkiner, H. Granger-causality between transportation and GDP: A panel data approach. Transp. Res. Part A Policy Pract. 2014, 63, 43-55. [CrossRef]

23. Gao, Y.; Zhang, Y.P.; Li, H.J.; Peng, T.; Hao, S.Q. Study on the Relationship Between Comprehensive Transportation Freight Index and GDP in China. Procedia Eng. 2016, 137, 571-580. [CrossRef]

24. Fan, S.G.; Chan-Kang, C. Regional road development, rural and urban poverty: Evidence from China. Transp. Policy 2008, 15, 305-314. [CrossRef]

25. Haklay, M.; Weber, P. OpenStreetMap: User-Generated Street Maps. IEEE Pervasive Comput. 2008, 7, 12-18. [CrossRef] 
26. OpenStreetMap. Stats-OpenStreetMap Wiki [Online]. Available online: https://wiki.openstreetmap/wiki/ .orgStats (accessed on 20 June 2020).

27. Over, M.; Schilling, A.; Neubauer, S.; Zipf, A. Generating web-based 3D City Models from OpenStreetMap: The current situation in Germany. Comput. Environ. Urban Syst. 2010, 34, 496-507. [CrossRef]

28. Fonte, C.C.; Martinho, N. Assessing the applicability of OpenStreetMap data to assist the validation of land use/land cover maps. Int. J. Geogr. Inf. Sci. 2017, 31, 2382-2440. [CrossRef]

29. Fonte, C.; Minghini, M.; Patriarca, J.; Antoniou, V.; See, L.; Skopeliti, A. Generating Up-to-Date and Detailed Land Use and Land Cover Maps Using OpenStreetMap and GlobeLand30. ISPRS Int. J. Geo-Inf. 2017, 6, 125. [CrossRef]

30. Bittner, C. Diversity in volunteered geographic information: Comparing OpenStreetMap and Wikimapia in Jerusalem. GeoJournal 2016, 82, 887-906. [CrossRef]

31. Mobasheri, A. A Rule-Based Spatial Reasoning Approach for OpenStreetMap Data Quality Enrichment; Case Study of Routing and Navigation. Sensors 2017, 17, 2498. [CrossRef]

32. Zhou, Q. Exploring the relationship between density and completeness of urban building data in OpenStreetMap for quality estimation. Int. J. Geogr. Inf. Sci. 2018, 32, 257-281. [CrossRef]

33. Goetz, M.; Zipf, A. Towards defining a framework for the automatic derivation of 3D CityGML models from volunteered geographic information. Int. J. 3-D Inf. Model. 2012, 1, 1-16. [CrossRef]

34. Hennig, S. OpenStreetMap used in protected area management. The example of the recreational infrastructure in Berchtesgaden National Park. J. Prot. Mt. Areas Res. Manag. 2017, 1, 30-41. [CrossRef]

35. Mobasheri, A.; Sun, Y.; Loos, L.; Ali, A. Are Crowdsourced Datasets Suitable for Specialized Routing Services? Case Study of OpenStreetMap for Routing of People with Limited Mobility. Sustainability 2017, 9, 997. [CrossRef]

36. Juhász, L.; Hochmair, H.H. How do volunteer mappers use crowdsourced Mapillary street level images to enrich OpenStreetMap? In Proceedings of the 20th AGILE Conference on Geo-Information Science, Wageningen, The Netherlands, 11 May 2017; pp. 18-21.

37. Zhang, Y.J.; Li, X.M.; Wang, A.M.; Bao, T.L.; Tian, S.Z. Density and diversity of OpenStreetMap road networks in China. J. Urban Manag. 2015, 4, 135-146. [CrossRef]

38. Goetz, M. Towards generating highly detailed 3D CityGML models from OpenStreetMap. Int. J. Geogr. Inf. Sci. 2013, 27, 845-865. [CrossRef]

39. Wang, Z.Y.; Zipf, A. Using Openstreetmap Data to Generate Building Models with Their Inner Structures for 3D Maps. ISPRS Ann. Photogramm. Remote Sens. Spat. Inf. Sci. 2017. [CrossRef]

40. Bergman, C.; Oksanen, J. Conflation of OpenStreetMap and Mobile Sports Tracking Data for Automatic Bicycle Routing. Trans. GIS 2016, 20, 848-868. [CrossRef]

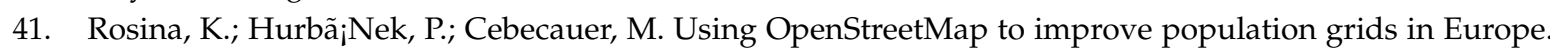
Am. Cartogr. 2016, 44, 139-151. [CrossRef]

42. Zhao, P.X.; Jia, T.; Qin, K.; Shan, J.; Jiao, C.J. Statistical analysis on the evolution of OpenStreetMap road networks in Beijing. Physica A 2015, 420,59-72. [CrossRef]

43. Dingil, A.E.; Schweizer, J.; Rupi, F.; Stasiskiene, Z. Updated Models of Passenger Transport Related Energy Consumption of Urban Areas. Sustainability 2019, 11, 4060. [CrossRef]

44. Shang, Y.S.; Liu, S.G.; Liu, C.Y.; Yin, P. Spatial-temporal characteristics of urbanization efficiency in coastal cities of China. In Proceedings of the 7th Annual International Conference on Geo-Spatial Knowledge and Intelligence, Guangzhou, China, 20-21 December 2019. [CrossRef]

45. Zou, Y.F.; Deng, M.; Li, Y.J.; Rong, Y. Evolution characteristics and policy implications of new urbanization in provincial capital cities in western China. PLoS ONE 2020, 15, e0233555. [CrossRef]

46. Haklay, M. How good is volunteered geographical information? A comparative study of OpenStreetMap and Ordnance Survey datasets. Environ. Plan. B Plan. Des. 2010, 37, 682-703. [CrossRef]

47. Zielstra, D.; Zipf, A. A comparative study of proprietary geodata and volunteered geographic information for Germany. In Proceedings of the 13th AGILE International Conference on Geographic Information Science, Guimarães, Portugal, 10-14 May 2010.

48. Neis, P.; Zielstra, D.; Zipf, A. The street network evolution of crowdsourced maps: OpenStreetMap in Germany 2007-2011. Future Internet 2012, 4, 1-21. [CrossRef]

49. Girres, J.-F.; Touya, G. Quality assessment of the French OpenStreetMap dataset. Trans. GIS 2010, 14, 435-459. [CrossRef] 
50. Luo, L.C.; Liu, B.; Liu, X.C. Data Quality Assessment and Application Analysis for OpenStreetMap Road Network. Jiangxi Sci. 2017, 35, 151-157.

51. Hecht, R.; Kunze, C.; Hahmann, S. Measuring Completeness of Building Footprints in OpenStreetMap over Space and Time. ISPRS Int. J. Geo-Inf. 2013, 2, 1066-1091. [CrossRef]

52. Singh Sehra, A.; Singh, J.; Singh Rai, H. Assessment of OpenStreetMap Data-A Review. Int. J. Comput. Appl. 2013, 76, 17-20.

53. Ludwig, I.; Voss, A.; Krause-Traudes, M. A comparison of the street networks of Navteq and OSM in Germany. In Advancing Geoinformation Science for a Changing World; Geertman, S., Reinhardt, W., Toppen, F., Eds.; Springer: Berlin, Germany, 2011; pp. 65-84.

54. Zhang, J.; Chen, J. Introduction to China's new normal economy. J. Chin. Econ. Bus. Stud. 2017, 15, 1-4. [CrossRef]

55. Li, C.; Zhang, X.J. Renminbi Internationalization in the New Normal: Progress, Determinants and Policy Discussions. China World Econ. 2017, 25, 22-44. [CrossRef]

56. Montgomery, D.C.; Peck, E.A. Introduction to Linear Regression Analysis; Wiley: Hoboken, NJ, USA, 1982.

57. Hawbaker, T.J.; Radeloff, V.C.; Hammer, R.B.; Clayton, M.K. Road density and land scape pattern in relation to housing density, and ownership, land cover, and soils. Landsc. Ecol. 2005, 20, 609-625. [CrossRef]

58. Shen, J.; Wu, R. Urban Road and Transportation; Wuhan University Press: Wuhan, China, 2006. (In Chinese)

59. Zhang, Q.; Wang, J.; Peng, X.; Gong, P.; Shi, P. Urban built-up land change detection with road density and spectral information from multi-temporal Landsat TM data. Int. J. Remote Sens. 2002, 23, 3057-3078. [CrossRef]

60. Feng, Z.; Liu, D.; Yang, Y. Evaluation of transportation ability of China: From county to province level. Geogr. Res. 2009, 28, 419-429.

61. Jin, F.J.; Wang, C.J.; Li, X.W. Discrimination method and its application analysis of regional transport superiority. Acta Geogr. Sin. 2008, 63, 787-798.

62. Savaş, B. The Relationship between Population and Economic Growth: Empirical Evidence from the Central Asian Economies. Orta Asya Kafkasya Araştırmaları 2008, 6, 135-153.

(C) 2020 by the authors. Licensee MDPI, Basel, Switzerland. This article is an open access article distributed under the terms and conditions of the Creative Commons Attribution (CC BY) license (http://creativecommons.org/licenses/by/4.0/). 